\title{
XIX. Yüzyıl Osmanlı Başkentinde Entelektüel Bir Acem: Mirza Habib İsfehanî ve Terekesi
}

\author{
Filiz Dı̆̆ıroğlu*
}

\section{A Persian Intellectual in the $19^{\text {th }}$ Century Ottoman Capital: Mirza Habib Isfahani and His Tereke}

\begin{abstract}
There exists a relatively extensive literature relating to the biography and the intellectual and political identity of the nineteenth century intellectual adversary Mirza Habib Isfahani, who spent half of his life in the Istanbul in exile, where soon after his arrival he became a celebrated figure in intellectual circles. His acclaim was a consequence of his literary scholarship as the author of a number of Persian works on grammar; his authorship of Hatt ve Hattatân; his translation of Sergüzeşt-i Hacı Baba-yı Isfehanî; and his contributions to the newspaper Akhtar, the first and longestrunning Persian newspaper published in the Ottoman capital. This literary scholar was also a civil servant of the Ottoman state. By focusing on Mirza Habib Isfahani's tereke (the bequest of possessions) this articles will attempt to shed light on his biography and intellectual world. Moreover, owing to the fact that a significant part of this possessions consisted of books and manuscripts left behind by this important nineteenth-century figure, this examination will provide information pertaining to the literary legacy of Ottoman and Iranian intellectuals of the period.
\end{abstract}

Keywords: Mirza Habib Isfahani, Istanbul, Persian, Iranian Intellectual, Persian language and Literature, Booklist

* Marmara Üniversitesi. Mirza Habib İsfehanînnin terekesinden beni haberdar ederek bu makalenin ortaya çıkmasına vesile olan hattat Talip Mert'e, Mirza’nın kütüphanesindeki birkaç kitap adının okunmasında yardımlarını esirgemeyen Mustafa Çiçekler'e, metrukâttaki bazı Farsça ifadelerde müşkillerimi halleden Turgay Şafak'a, makaleyi okuyup, eleştirileri ile katkıda bulunan Bilgin Aydın ve Fulya İbanoğlu'na müteşekkirim. Makale yazım aşamasında iken yaptığımız sohbetlerle Mirza Habib'e yaraşır bir metin ortaya çıkması hususundaki alakasını metni defalarca okuyarak da gösteren Güllü Yıldız’a sabrı ve katkıları için hassaten teşekkür ederim. Yayınlanmadan evvel okudukları makaleye yaptıları katkının hakkını teslim etmek için Tanya Lawrance ve Ali Akyıldız’a teşekkürü borç bilirim. Tereke ve kitap terekeleri konusundaki engin bilgisini benimle cömertçe paylaşıp, terekedeki bazı ayrıntılara dikkatimi çeken İsmail E. Erünsal'a ne kadar teşekkür etsem azdır ve elbette her zaman olduğu gibi bu makaleyi de okuyarak lütfettiği kıymetli eleştirileri ile metnin daha muhkem bir metin olmasını sağlayan İsmail Kara’ya müteşekkirim. 
XIX. yüzyıl İstanbulu'nun Tophane semtinde, zevkli İrankâri eşyalarla döşenmiş güzel bir ev... Kaçar hanedanından Müeyyidülmülk'ün Avrupa seyahatinin İstanbul durağında, maiyetindeki Hacı Muhammed Ali Pirzade (ö. 1903/4) ve Hacı Mirza Hasan Han'ın da ağırlandığı bu ev; İran, Avrupa ve İstanbul'dan gelen ve büyük kısmını entelektüellerin oluşturduğu seçkin misafirlerin uğrak yeridir. ${ }^{1}$ Sayısız ilim, kültür ve sanat meclislerine ev sahipliği yapan bu evde, her zaman olduğu gibi o akşam da çok özel iki misafire, İran'dan gelen dostlara bir akşam yemeği verilir. ${ }^{2} 20$ yıl aradan sonra ikinci defa geldiği İstanbul'da Hacı Muhammed Ali Pirzade ile Hacı Mirza Hasan Han, bu mutantan evde hazırlanmış mükellef bir sofrada yemeklerini yedikten sonra güzel eşyalar ve kitaplarla donatılmış bir başka odaya geçerler. ${ }^{3}$ Herhalde kahvelerini Mirza Habib İsfehanî̀nin sadece özel dostlarının ziyaret edebildiği bu kütüphanede içerler. Mirza Habib, misafirlerine İstanbul'un zengin sahaf ve kitapçılarından özenle toplanmış murakkaları, kitapları ve eşyaları tek tek gösterir. İstanbul'un nimetlerinden sonuna kadar faydalanan Mirza, kütüphanelerde çalışarak elde ettiği yeni şiir mecmualarını misafirlerine büyük bir keyifle ziyaret ettirir. Varlıklı, entelektüel ve muhibb-i kütüb bir Farisî olarak İstanbul'da hayatını sürdüren Mirza Habib'in bu denli zengin bir kütüphane oluşturmasına şaşmamak gerekir. Hat ve edebiyat başta olmak üzere çeşitli zevk ve merakları olan Mirza gibi bir entelektüelin XIX. yüzyıl sonlarındaki İstanbul kitap piyasasının zenginliği ve hareketliliği ile mütenasip olarak vasıflı bir kütüphane oluşturduğuna hiç şüphe yoktur. ${ }^{4}$ İstanbul'da topladığ 1

1 Bu ev Mirza Habib İsfehanînnin ikametgahı olan Tophane'deki Defterdar Ebu'l-fazl mahallesi, 29 numaralı hane olmalıdır. Başbakanlık Osmanlı Arşivi (Bundan sonra BOA), MF TLY 20/63, 28 Şevval 1310/15 Mayıs 1893.

2 Avrupa'ya tedavi maksadıyla yolculuk yapan Kaçar hanedanından Müeyyidülmülk’ün maiyetindeki Hacı Muhammed Ali Pirzade bir derviş, İran devlet erkanından Mirza Hacı Hasan ise bir subaydı. Bu vesile ile 1886-1889 yıllarını Tahran'dan Londra'ya seyahat ederek geçiren Pirzade, İran seyahatname/sefername literatüründe önemli bir yer tutan seyahatnamesini kaleme alır. Hacı Muhammed Ali Pirzade, Sefername-i Hacı Pirzade, haz. Hafiz Ferman Fermaiyan, (Tahran 1963), I, Mukaddime s. 25.

3 Bu yemek ziyafetini ve kütüphane ziyaretini günlüklerine kaydederek bize ulaşmasını sağlayan Hacı Muhammed Ali Pirzade'dir. Sefername-i Hacı Pirzade, II, s. 96.

4 "O sahaflar vaktiyle müreffeh idiler. Ramazanlarda Bayezid ve Fatih camilerinde sergiler açarlar, türlü kitaplar yayarlar idi. Buraya sadrazamlar, vezirler, ilim meraklıları gelir alış-veriş ederlerdi. Benim bildiğim Ahmed Vefik Paşalar, Said Paşalar, Rıza Paşalar hep bu sergilerin müdavimi idi. Sahaflar böyle sergi ile de kalmazlardı. Ellerinde birer çıkın kitap ile her gecelerini bir kitap muhibbinin yalısında, konağında geçirirler idi”. Necip Asım, "Kitapçllı", İkdam, c. 53, no. 8937, 2 Cemaziyelahir 1340, s. 3; İstanbul kitap piyasası ve sahafları hakkında ayrıntılı 
murakkalar, kitaplar ve eşyaları hayranlıkla izleyen misafirler Mirza’nın bu kadar zengin bir koleksiyon oluşturabilmesini maddi olarak rahat bir hayat sürebilmesine bağlamışlardır. Pirzade bu ziyafet sonrasında günlüğüne yazdığı satırlarda, İstanbul'da İran'da olmayan birçok kitaba rahat bir şekilde ulaşabilmesinin hem bu kadar zengin bir kitaplık oluşturmasına hem de velud bir yazar olmasına imkan tanıdığına dikkat çeker.

Yukarıda anlatılan bu zevkli evin ve meşhur kütüphanenin sahibi Mirza Habib İsfehanî kimdi? XIX. yüzyılın ortalarında kaçak olarak geldiği Osmanlı başkentinde, son derece tanınan bir şahıs haline gelen Mirza Habib’in oldukça ilginç bir hayat hikayesi vardır. Farsça ve Fransızca muallimliğinin yanı sıra müellifliği, mütercimliği sayesinde Dersaadet'in entelektüel muhitlerinde kısa sürede aranan isimlerden biri haline gelir. Osmanlı bürokrasisindeki yirmi beş yıllık memuriyet tecrübesiyle birlikte Farsça ders kitapları yazarı, Sergüzeşt-i Hacı Baba-yı

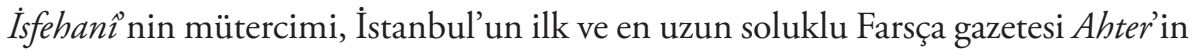
yazarlarından biri ve Osmanlı entelektüel camiasında Hat ve Hattatân yazarı olarak haklı bir şöhrete sahip olur.

Mirza Habib'in biyografisi, entelektüel ve siyasi kimliği hakkında oldukça zengin bir literatür vardır. Terekesine odaklanan bu makale ile söz konusu zengin literatüre küçük bir katkı yapmak hedeflenmektedir. Terekesi, sahibinin çok yönlü kişiliğine uygun olarak birkaç açıdan ele alınabilir. Herşeyden önce Maarif Nezareti'nde hem muallim hem de sansür/kontrol memuru olarak görev yapan Habib Efendi'nin terekesi olması açısından değerlendirilebilir. Bu bağlamda Mirza Habib'in terekesi XIX. yüzyıl Osmanlı bürokrasisindeki bir memurun ölümünden sonra ardında bıraktıklarına dair bir takım ayrıntılar sunmaktadır. Habib Efendi'nin ardında bıraktığı eşya listesindeki ayrıntılar, son dönem Osmanlı İstanbulu'ndaki evlerden birinde ne tür eşyalar kullanıldığına dair malumatı arttırarak maddi kültür tarihi çalışmalarına katkı sağlayacaktır. İkinci olarak Mirza Habib'in terekesi XIX. yüzyıl Fars edebiyatının önemli figürlerinden birinin ardında bıraktığı eşyaları ve özellikle kitaplarını göstermesi açısından anlamlıdır. Maarif Nezareti'nin Farisî kökenli memuru Habib Efendi'nin şair ve entelektüel kişiliği ile mütenasip olarak ardında bıraktığı eşyaların büyük bir kısmını kitapları

bilgi için bkz. İsmail E. Erünsal, Osmanlılarda Sahaflık ve Sahaflar (İstanbul: Timaş Yayınları, 2014); 19. asır İstanbulu'nda ilim, kültür ve sanat meclisleri hakkında yapılmış vasıflı bir çalışmanın kütüphaneler ve sahaf dükkanları kısmı için bkz. Şemsettin Şeker, Ders ile Sohbet Arasında: On dokuzuncu Asır İstanbulu'nda İlim, Kültür ve Sanat Meclisleri, (İstanbul: Zeytinburnu Belediyesi 2013), s. 135-140. 
oluşturmaktadır. Terekede Bezzazistân'da satılan kitaplarının bir listesi verilmiştir. Sadece Habib Efendi'nin telif eserlerinin listesi ile ardında bıraktığı kitaplığın listesi yan yana geldiğinde bile, Osmanlı/İran entelektüel hayatına dair pek çok ipucunu barındıran bir tablo ortaya çıkacağı düşünülmektedir. Makaleye konu olan tereke ile Habib Efendi'nin bilinen biyografisine yeni bilgiler eklenmekle beraber esasen entelektüel biyografisine katkı sağlamak hedeflenmektedir. Kendisinin İran kökenli olması, çalışmayı XIX. yüzyıl Osmanlı başkentinde yaşayan Acem topluluğu ile doğrudan ilişkilendirse de çalışmanın sınırları açısından bu mevzu dışarıda bırakılacaktır. ${ }^{5}$

\section{Tercüme-i Ahvali: Muhalif, Muallim, Müellif, Mütercim}

Habib Efendi'nin aile hayatına, gündelik yaşamına ve özellikle kütüphane listesi ile entelektüel dünyasına dair ayrıntıların görüleceği terekesi, biyografisi hakkında zengin ama sınırlı bir malzeme sunmaktadır. ${ }^{6}$ Bu sınırlı malzeme mevcut literatürle birlikte değerlendirildiğinde kıymeti artacaktır.

5 İstanbul'daki İranlılar hakkında bugüne kadar yapılmış en kapsamlı çalışma için bkz. Les Iraniens (ed. T. Zarcone-F. Zarinebaf), (İstanbul-Teheran 1993); Yine İstanbul'da Acem bir kitapçının biyografisi ve mesleki faaliyetlerini ele alan son dönemde yapılmış çalışmalardan birisi için bkz. Filiz Dığıroğlu, Dersaadette Acem Bir Kitapçı: Kitap-füruş Hacı Hüseyin Ağa, (İstanbul: Turkuaz Yayıncılık 2014); İstanbul'daki İranlıların merkezi mahiyetindeki Validehan hakkında yapılmış bir çalışma için bkz. Filiz Dığıroğlu, "İstanbul-Tebriz Ticaret Hattında Validehan (XIX-XX. Yüzyıl)”, Türk Kültürü İncelemeleri Dergisi, 31, (2014), s. 69-112; Ayrıca İstanbul'daki ilk Farsça gazete olan Ahter'i merkeze alsa da İstanbul'daki Acem topluluğunu da içeren son yıllardaki bir çalışma için bkz. Tanya E. Lawrance, Akhtar: A Persian Language Newspaper Published in Istanbul and the Iranian Community of the Ottoman Empire in the Late Nineteenth Century, (İstanbul:Libra Yayıncılık 2015). Osmanlı ve İran entelektüellerinin etkileşimi ile ilgili olarak son dönemde yapılmış çalışmalardan birkaçı için bkz. Yılmaz Karadeniz, "İran'da Malkum Han ve Feth Ali Ahundzâde’nin Arap Alfabesini Değiştirme Teşebbüsleri (1860-1880)”, History Studies, Enver Konukçu Armă̆anı, (2012), s. 215-226, Enis Erdem Aydın, "Sultan Abdülaziz Döneminde Alfabe Tartışmaları: 'Huruf-1 Mukatta' ve Geç Tanzimat Zihniyeti”, Sultan Abdülaziz Dönemi ve Sempozyumu: Sosyo-Kültürel İlişkiler (Ankara: Türk Tarih Kurumu 2014), I, s. 139-152; Gholamali Pashazadeh, "Müsteşar'ul Devle ve Abdülaziz Dönemi Reformcularından Etkilenmesi”, Sultan Abdülaziz Dönemi ve Sempozyumu: Sosyo-Kültürel İlişkiler, 3, (Ankara: Türk Tarih Kurumu 2014), s. 155-170.

6 Bu sınırlılığı aşmak için ilk olarak mevcut literatür taranmış, ardından Nevsal-i Servet-i Fünûn gibi dönem kaynaklarındaki biyografik malumata başvurulmuştur. Aynı zamanda metrukatı arasında yer alan, kendi el yazısıyla yazdığı yarım sayfayı geçmeyen biyografisi de değerlendirilmiştir. Daha sonra Başbakanlık Osmanlı Arşivi’nde Habib Efendi hakkında bulunan memuriyeti, atama, terfi, maaş bilgileri ve Maarif Encümeni'ndeki görevi ile ilgili belgelerle biyografisi 
Mirza Habib Efendi, 1251 (1835/36)'de İsfehan'ın bir köyünde dünyaya gelir. İsfehan'da bir müddet ilim tahsil ettikten sonra memur ve gayet mutaassıb olan babası ile fikri anlaşmazlıklar yaşayınca öğrenim hayatını sürdürmek için Tahran'a gider. Bir süre Tahran'da tahsiline devam eden M. Habib, daha sonra Bağdat'a gidip dört sene boyunca edebiyat, fikıh ve usul tahsil edip, Tahran'a döner. $^{7}$

Bağdat'tan Tahran'a dönüşünde Nasırüddin Şah'ın amcasının oğlu ile birlikte İran'ı istibdattan kurtarmaya çalışır. Bu esnada sadrıazam sipehsalar Mehmed Han'ı hicv ettiği için İran'dan kaçmak zorunda kalır. ${ }^{8}$ Şah taraftarlarının galebesi üzerine Tahran'dan firar eder ve iki ay Rumiye'de bir Fransız manastırında kalır. Papazların verdiği bir merkep ve 5 lira ile yola çıkan Mirza Habib, düşmanları tarafından takip edilerek yaralanır. ${ }^{9}$ Tabi bu yolculuk esnasında başına gelmeyen kalmaz. Yaralı olarak girdiği Osmanlı topraklarında, İstanbul'a ulaşması biraz zaman alır. Sefir Müşirüddevle Hacı Mirza Hüseyin Han zamanında İstanbul'a ulaşan Mirza Habib’e İran sefiri iltifat etmemiştir. ${ }^{10}$ Bir kaçak olarak 1283'te (1866/67) geldiği İstanbul'da Osmanlı Devleti'ne iltica eder.

desteklenmiştir. Maalesef memuriyeti ile ilgili olarak sicil varakasına rastlanılmamıştır. Maarif Nezareti dosyalarında Sicill-i Ahval Reisi'nin Habib Efendi'nin memuriyetlerini soran bir yazışması dışında henüz terceme-i hal varakası ya da hizmet cetveli gibi evraka rastlanmamıştır. "Encümen-i Teftiş ve Muayene azasından Habib Efendi'nin bazı memuriyetleri istifsarını havi 21 Şaban 1309 tarihli ve bir numaralı tezkire-i acizi cevabının lütfen bir an evvel işar ettirilmesi babında emr u ferman hazret-i men lehu'l-emrindir” BOA, MF SCL 2/19, 28 Zilhicce 1309/24 Temmuz 1892.

Mevcut literatüre kaynaklık eden İbnülemin Mahmut Kemal İnal, Son Asır Türk Şairleri, c. I, MEB, İstanbul 1969, s. 472-474 ve Ali Alparslan, "Habib Efendi”, Türkiye Diyanet Vakfi Íslâm Ansiklopedisi (Bundan sonra DİA), c. 14, s. 370-371. Kısa biyografisinin yer aldığı bazı kaynaklar için ayrıca bkz. Türk Dünyası Ortak Edebiyatı: Türk Dünyası Edebiyatçıları Ansiklopedisi, c. IV, Ankara 2004, s. 307-308; Türk Dili Edebiyatı Ansiklopedisi, c. III, s. 440; Vasıflı bir biyografisi için bkz. Şerifî, "Habib İsfehanî”, Danişnâme-i Edeb-i Fârisî//6, Edeb-i Fârisî der Anadolu ve Balkan, Tahran 1383, s. 312-317; http://www.iranicaonline.org/articles/habib-esfahani (erişim tarihi 23.01.2015)

7 Habib İsfehani, Mecmua-i Eş่ar ve Fevaid, İstanbul Üniversitesi Nadir Eserler Kütüphanesi, no. FY 712, s. 42; İnal, s. 472.

8 Bu ifadenin de yer aldığı kendi el yazısı ile yazılmış tercüme-i hali ektedir. İsfehani, Mecmua-i Eş’ar, 42; Bu biyografi için bkz. EK 1 .

9 Süleyman Nazif'in talebi üzerine Habibzâde Kemal Bey tarafından yazılan tercüme-i halinde yer alan bu satırlar için bkz. İnal, s. 472.

10 Sefername-i Hacı Pirzade, s. 95. 
Arapça ve Farsça bilgisi, entelektüel kişiliği ve sahip olduğu meziyetler İstanbul'da hemen tanınmasına vesile olur ve Sadrazam Âli Paşayya takdim edilir. Âli Paşa ve Ahmed Vefik Efendi'nin himayesi ile Galatasaray Mekteb-i Sultanisi'nde Arapça ve Farsça muallimliği yapar. İstanbul'a geldikten iki sene sonra Şah'ın adamları Habib’i öldürene para vaadinde bulunur. Oturduğu odanın sahibi olan Ermeni, Acemce bildiğinden keyfiyeti istihbar ve ihbar ederek Habib Efendi'nin kurtulmasını sağlar. Habib Efendi ders verdiği İngiltere sefareti baş tercümanı vasıtasıyla 15 gün sefarette kaldıktan sonra Osmanlı tabiyetine geçer ve suikasttan kurtulur. ${ }^{11}$

İstanbul'a geldiği andan itibaren dil dersleri veren Habib Efendi'nin Mekteb-i Sultani'deki hocalığı 12 yıl sürer. ${ }^{12}$ Darüşşafaka’nın kuruluşundan itibaren Farsça ve Fransizca derslerini veren Habib Efendi, mülga Lisan Mektebi'nde de muallimlik yapar. İbnülemin'in yazdığı biyografide Ali Suavi vakasından sonra mektepten alınıp Maarif Nezareti'nde Encümen-i Teftiş ve Muayene ${ }^{13}$ azalığına tayin edildiği kayıtlıdır. ${ }^{14}$ Encümen azalı̆̆ı ile son derece kritik bir vazifeye atanan Habib Efendi'nin bu göreve getirilmesi, devlet nezdinde kendisine olan güveni göstermektedir.

Habib Efendi Encümen'deki vazifesinde hem Farsça hem de Fransızcasını kullanmış olmalıdır. Rastladığımız örnekler Fransızca kitaplar ve Fransızcasını kullandığına şahitlik etse de Farsça kitaplarla ilgilendiğine de şüphe yoktur. İncelemek üzere kendisine gönderilen kitaplardan Slav dilinde yazıldığı zannedilen bir kitabın Fransızca olduğunu tespit edip, içeriğinin de sakıncalı olduğuna kanaat getirmiş ${ }^{15}$; bunun gibi ciltlerce Fransızca kitaba içerikleri "muzır" olduğu gerekçesiyle onay vermemiştir. Bu kitaplardan bazıları Tibet histoire de Mubej(?) (3 cilt), Tibet histoire (26 cilt), Tibet histoire générale (13 cilt), Magasine Zuzel Fan(?)

11 İnal, s. 472.

121310 senesine mahsus Nevsal-i Servet-i Fünûn, (İstanbul 1311), s. 84.

13 Encümen-i Teftiş ve Muayene hakkında ayrıntılı bilgi için bkz. Ali Birinci, "Osmanlı Devleti’nde Matbuat ve Neşriyat Yasakları Tarihine Medhal”, Tarihin Hududunda Hatırat Kitaplar, Matbuat Yasaklar ve Arşiv Meseleleri, (İstanbul 2012), s. 142-145.

14 Encümen'de görevlendirilmesine dair resmi yazışmalardan 12 Teşrin-i evvel 1298/24 Ekim 1882'de aylık 500 kuruş maaşla Encümen'de Farş̧a kitapları muayeneye memur olduğu, 25 Kanun-1 evvel 1300/ 6 Ocak 1885'de de Encümen azalığına tayin olduğu anlaşılmaktadır. 9 Eylül 1305/21 Eylül 1889'da padişah iradesiyle memuriyetinden affolunduğu halde 17 Mart 1307/29 Mart 1891'de tekrar 1335 kuruş maaşla Encümen azalığına tayin kılındı. BOA, Maarif Nezareti Mektubi Kalemi (Bundan sonra MF MKT) 145/132, 29 Zilhicce 1309/25 Temmuz 1892.

15 BOA, MF MKT 87/149, 20 Zilhicce 1302/30 Eylül 1885. 
ve Alber[t] Kohen’in tercüme-i halidir. ${ }^{16}$ İçeriğinde "muzır" bir ifade olmadığını tespit ettiği Monde Illustré, Voyage en Urban gibi eserlerin gümrük geçişlerine izin vermiş; bu tür Fransızca neşriyatın Osmanlı topraklarında tedavüle girmesini sağlamıştır. ${ }^{17}$ Vazifesini ehliyetle yapmış olmalı ki, memuriyeti boyunca nişanlarla ve maaş zamlarılla taltif edilmiştir.

Encümen azası Habib Efendi'nin memuriyet makamında kademeli olarak rütbe ve maaş zammı aldığı görülmektedir. Başbakanlık Osmanlı Arşivi'nde Habib Efendi'nin rütbe ve maaşının arttırılması ile ilgili yazışmalarda İran sefirinin de aktif olarak yer aldığ tespit edilmiştir. Şah rejiminden kaçan ve artık Osmanlı vatandaşı olan bir İranlı için sefirin talepte bulunması dikkate değerdir. Bu durum İstanbul'da yaşayan Acem topluluğunun kendi aralarındaki basit bir dayanışma örneğinin ötesinde anlamlar ifade etmelidir. İran sefiri "Arapça, Farsça, Fransızca bilen şiir sanatında mahir ve akranlarından üstün” olduğuna inandığg hemşehrisi Habib Efendi'nin terfi etmesini istemiş, bu talebi de padişah tarafından uygun görülmüştür. ${ }^{18} 1$ Ocak $1885^{\prime}$ te Habib Efendi’nin çalışkanlığı sebebiyle kendisine rütbe-i salise tevcih edilmiş, 850 kuruş olan maaşı da 1200 kuruşa çıkarılmıştır. ${ }^{19}$ 1886 yılının sonlarına doğru Habib Efendi’nin “erbab-ı fazıl ve ehliyetten olması cihetiyle" sahip olduğu rütbenin terfisine karar verilmiştir. ${ }^{20}$

İstanbul seyahati esnasında Mirza'yı evinde ziyaret eden ünlü seyahatname yazarı Pirzade'ye göre halihazırda Maarif'teki hizmetine karşılık 40 tümen aylık alıyordu. Devlet hizmeti dolayısıyla sabit ve düzenli bir gelirinin yanında

16 Bu husustaki örnekler için bkz. BOA, MF MKT 86/73, 87/29, 87/30.

17 BOA, MF MKT 87/74; 87/28.

18 BOA, İrade-i Dahiliye (Bundan sonra İ.DH) 935/74062, 10 Safer 1302/29 Kasım 1884; Kendisi de şair olan sefir Muinülmülk Hacı Şeyh Muhsin Han’ın Mirza Habib’e paye istenmesine aracı olmasında Mirza’nın kendisine yazdığı kasidelerin payı var mıdır? Bu sorunun cevabı tam olarak bilinemese de Mirza’nın kendi el yazısıyla yazdığı biyografisindeki “İran sefirine [Muinülmülk] bazen kaside yazardım ama diğer şairler gibi hediyede gözüm yoktu” ifadeleri bu ihtimali düşündürmektedir. Bu ihtimali belki de söylentiyi bertaraf etmek için otobiyografisinde özellikle "hediyede gözüm yoktu" ifadesini kullanmayı tercih etmiş olabilir. Sefir Muinülmülk’ün 18 yıl süren İstanbul sefareti ve Sultan Abdülhamid ile olan dostluğu hakkında ayrıntılı bilgi için bkz. Han Melik Sasani, Payitahtın Son Yillarında Bir Sefir, mütercim Hakkı Uygur, İstanbul 2006, s. 201-209; Mirza Habib'in Muinülmülk'e yazdığı üç kasidenin birer mukaddimeyle birlikte Ahter'de yayınlanması hakkında bkz. Rahim Reis Niya, Iran ve Osmanî der Astane-i Karn-ı Bistum, I, (Tahran 1328 hş.), s. 513.

19 BOA, İ.DH 937/74233, 14 Rabiülevvel 1302/1 Ocak 1885.

20 BOA, İ.DH 1002/79172, 20 Zilhicce 1303/19 Eylül 1886. 
birçok yerde verdiği derslerden elde ettiği nakit para sayesinde maddi olarak rahatı yerinde idi. İranlıların okulunda ders verdiği gibi Muinülmülk'ün sefirliği esnasında Sefarethane'ye de hizmet veriyor ve bu hizmetlerinin karşılığında bir gelir elde ediyordu. ${ }^{21}$ İran'ın İstanbul elçisi Han Melik Sasani de hatıralarında Mirza Habib’in İran okulunda Fars edebiyatı derslerini verdiğini kaydetmiştir. ${ }^{22}$

Mizah şairi ve Hacı Baba-yı İfehanînin usta çevirmeni Mirza Habib İsfehanî, 1866 'da geldiği İstanbul'da ömrünün sonuna kadar kitap telifi ve basımıyla uğraştı. 27 yıllık İstanbul hayatı boyunca onun evi, İran edebiyatı ve İran meraklılarının merkezi haline geldi. Osmanlı Topraklarında Fars Dili ve Edebiyatı başlıklı kitabın yazarı Riyâhî̀ye göre; Habib, iyi bir araştırmacı, güçlü bir şair, usta ve zevk sahibi bir yazardı. İran'dan uzak kalışı ve hicivlerindeki pervasızlık nedeniyle makamına yaraşan bir şöhrete kavuşamamıştı. ${ }^{23}$ Dönemin prestijli mecmualarından Maarif, Habib Efendi'nin ilim ve irfanına meth u senalarda bulunduktan sonra Farsça ile alakalı en müsskil meselelerin kendisine müracaatla halledilebileceğini satırlarına taşımıştı. ${ }^{24}$ Görüldüğü üzere Mirza Habib İsfehanînnin hem İstanbul'daki Acem topluluğu için hayati önem arz eden kurum ve kişiler hem de Osmanlı Devleti'nin merkezindeki kurum ve kişilerden müteşekkil çevresine, İstanbul sefarethanelerindeki dostları da eklendiğinde, son derece renkli ve her kesimle sıkı ilişkiler kuran bir münevver portresi ortaya çıkmaktadır. Osmanlı başkentindeki yoğun işler ve karmaşık ilişkiler ağına rağmen, Debistan-1 İraniyan ve Ahter ${ }^{25}$ gibi Acem topluluğu için önemli kurumlardaki görevlerini hiç aksatmamış, İstanbul'daki hemşehrilerine hizmete devam etmiștir. Ahter'in müdürü Hacı Mirza Mehdi Tebrizi, hem Abter'de hem de Debistan'da birlikte çalıştığı Ağa Han-1 Kirmani ${ }^{26}$ ve Hüseyin

21 Sefername-i Hacı Pirzade, s. 96.

22 Sasani, s. 82; John Gurney, "E.G. Browne and The Iranian Community in Istanbul”, Les Iranians, s. 155.

23 Muhammed Emin Riyâhî, Osmanlı Topraklarında Fars Dili ve Edebiyatı, Türkçesi Mehmet Kanar, (İstanbul 1995), s. 262.

24 Maarif, sene 2, c. 4, nr. 97, s. 289.

25 İstanbul'da yayınlanan ve İran modernleşmesi açısından da önem arzeden Ahter' in (1876-1896) sahibi ve mesul müdürü Muhammed Tahir Tebrizînin matbaa ve yayıncılık faaliyetleri ile hakkında çok az şey bilinen biyografisine dair son dönemde yapılmış bir çalışma için bkz. Güllü Yıldız, "Osmanlı Matbuatının Farklı Bir Yüzü: Muhammed Tahir Tebrizı̂”, Türk Basın Tarihi Uluslararası Sempozyumu (19-21 Ekim 2016, Elazığ), (basılmamış sempozyum bildirisi). (Bildiri metnini benimle paylaşan Güllü Yıldız’a teşekkür ederim.)

26 Şehit şair, yazar ve düşünür Mirza Ağa Han-1 Kirmanî 1303/1886 yılı sonlarında İstanbul'a 
Daniş ile dostluğu, İstanbul'a yolu düşen münevverlerle yakından ilgilenmesi onu, İstanbul'daki Acem topluluğun merkezinde yer alan bir figüre dönüştürmektedir. Gerek Maarif Nezareti'ne bağlı Darüşşafaka ve Galatasaray gibi okullardaki muallimliği gerekse nezaretin merkezindeki Encümen-i Teftiş azalığı esnasında tesis ettiği ilişkiler, kurduğu ahbablıklar kendisine Osmanlı entelektüel/kibar muhitinde son derece müstesna bir yer edindirmiş olmalıdır. Destur-ı Suhan’’ İran sefiri Emir Nizam Gerusi'nin teşvikiyle hazırlaması ve yine Fransız sefiri Ferte'nin mukaddimesiyle hazırlanan Ubeydi Zakani müntehabatı onun İstanbul sefarethanelerindeki ilişkilerini göstermesi bakımından oldukça anlamlıdır.

Bir süredir hasta olan Mirza Habib, tedavi için Bursa'ya gider. İstanbul'dan son ayrılışı olacak tedavi maksatlı bu Bursa seyahatinde, 1 Mayıs 1309/13 Mayıs 1893 'de vefat eder. Henüz genç denebilecek bir çağda 58 yaşında bu dünyadan göçen Habib Efendi ${ }^{27}$, Bursa'nın Çekirge semtinde İranîler'e mahsus kabristana defn edilir. ${ }^{28}$ Geride üç erkek çocuğunu ve eşini bırakmıştır. ${ }^{29}$ Tophane'deki Defterdar Ebu'l-fazl mahallesinde ikamet eden Habib Efendi'nin ikinci evliliği Çerkez asıllı İkbal Hanımla’ydı. ${ }^{30}$ Geride bıraktığı yetimlerden biri, Habib Efendiden önce terk-i dünya eden ilk hanımı Fatımatüz-Zehra'dan doğan Mehmed Kemal Bey idi. Diğer çocuklar ise İkbal Hanım'ın dünyaya getirdiği Mehmed Cemal ve Ahmed Celal Beyler idi.

gelerek Mirza Habib’e katıldı ve yakalanıp, düşünceleri uğrunda hayatını verene kadar bu şehirde telif ve çeviri çalışmalarını yürüttü. Riyahi, age, s. 262; Kirmanî, Adliye veziri Rıza Paşa’nın isteği üzerine merhum Mirza’nın Jil Pilas tercümesini h. 1312'de istinsah etmiştir. Kirmanî̀nin istinsah ettiği bu nüsha İ.Ü. Nadir Eserler Kütüphanesi FY 294 numarada kayıtlıdır.

27 Ehibbâsından Burhanüddini Belhî Efendi şu tarihi söylemiştir: "Ah öldü bülbül-i bağ-1 cinan u can Habib 1310 sene-i hicriyye”, İnal, s. 474; vefatı üzerine Servet-i Fünun'da çıkan yazı için bkz. Servet-i Fünun, 24 Haziran 1909, c. 5, s. 121, s. 170 (Beni bu yazıdan haberdar eden Turgay Şafak’a teşekkür ederim).

28 Niya, s. 498.

29 Habib Efendi'nin eşi miras taksimatı konusunda "mütevehhim" olduğu için devlet makamlarına müracaat etmiştir. Bu konuda bkz. BOA, MF TLY, 20/63, 28 Şevval 1310/15 Mayıs 1893. Ayrıca gözü yaşlı eş, çocuklarının haklarının korunması noktasında hem miras taksimatında hem de daha sonraki süreçlerde oldukça etkin olmuştur: Habib Efendi'nin vefatından sonra padişahın himmeti ile babasının yıllarca hocalık yaptı̆̆ı Mekteb-i Sultani'ye kaydedilen 9 yaşındaki Celal Efendi, annesinin ricası ile okul masrafları ve elbise parasından muaf tutulmuştur. Bu konuda bkz. BOA, MF MKT 168/100, 4 Zilkaade 1310/20 Mayıs 1893; BOA, MF MKT 173/15, 18 Zilhicce 1310/3 Temmuz 1893.

30 Mirza Habib, ilk hanımı Fatmatü’z-Zehra Hanım’dan boşanarak Çerkez asıllı olan İkbal Hanım ile evlendi. Sefername-i Hacı Pirzade, s. 97. 
Fransa hükümeti birçok eseri bulunan Mirza Habib'e, Akademi nişanı ve Paris Cemiyet-i Asyaiyyesi azası ve fahri muhabiri ünvanını verir. ${ }^{31}$ Farsça dil öğretimine dair teorik ve Mekteb-i Sultani'deki hocalık vazifesi sebebiyle de pratik tecrübelerinden faydalanmak isteyen Osmanlı Devleti, Habib Efendi'yi Farsça ders kitapları hazırlaması için teşvik eder. Telif ettiği Destur/Düstur-ı Farisî adlı sarf ve nahiv kitabından rüşdiye muallimleri ve şakirdânı için satın alınarak bedelinin Maarif Nezareti'nin ilgili kalemlerinden karşılanmas ${ }^{32}$ ile alakalı evrak, Habib Efendi'nin orta öğretim Farsça dil eğitim kitapları yazması konusunda teşvik edildiğini göstermektedir. Ahter gazetesinde pek çok şiiri yayınlanan Habib Efendi'nin ders kitabı mahiyetinde birçok eserinin basılması hem bu konudaki ihtiyacı hem de devletin bu kitaplar için Mirza Habib'e verdiği desteği göstermektedir. Hulasa-i Rehnümâ-yı Fârisî̀ (İstanbul, Matbaa-i Osmaniye, 1309, II. baskısı 1316'da Karabet matbaasında yapılmıştır) ve Rehber-i Fârisî (İstanbul, Kasbar Matbaası, 1310; İstanbul Karabet Matbaası 1314; İstanbul Karabet Matbaası 1318; İstanbul, Babıali Caddesi 38 numaralı Matbaa 1320) adlı kitapları hazırladığı ders kitaplarının başında gelmektedir. ${ }^{33}$ Ders kitabı olarak sayılabilecek diğer eserleri şunlardır; Düstur-ı Sühan (İstanbul 1289), Debistan-ı Farisî̀ (İstanbul, Mahmut Bey Matbaası, 1308) ${ }^{34}$, Rehnuma-yı Farisî (İstanbul, Matbaa-i Osmaniye 1309; İstanbul, Matbaa-i Osmaniye 1312), Düsturçe (İstanbul, 1293; İstanbul Mihran Matbaası 1300; İstanbul Mihran Matbaası 1303; İstanbul Kasbar Matbaası 1313) ${ }^{35}$, Berg-i Sebz (İstanbul 1304, 1312), Müntehabât-ı Gülis$\tan$ (İstanbul, Mahmud Bey Matbaası 1309). ${ }^{36}$ Düsturce, yeni farsça okuyanlara

31 Nevsal-i Servet-i Fünun, s. 85; İnal, s. 474.

32 BOA, MF MKT 3/53, 28 Cemaziyelevvel 1289/3 Ağustos 1872.

33 Hülasa-i Rehnüma-yı Farisìnin ikinci baskısının girişindeki ifadeleri devlet tarafından Farsça ders kitapları hazırlamakla görevlendirildiğinin en açık delilidir: "Mekâtib-i İdâdiye’de tedrîs olunmak üzre hâlâ nâzır-1 umûr-1 Maarif-i umûmiye (devletlü Zühtü Paşa) hazretlerinin telîf ve tedvînini bende-i sermendleri (Habib) kim-nasibe emr ve havale buyurdukları (Rehnümây1 Fârisî) nam kavâid-i Fârisiye risalesinin mekâtib-i rüşdiyye için elverişli olmak üzere bir hülâsasının dahi tertibi müşârunileyh hazretleri tarafından emr buyrulmağla mucebince risale-i marûza ihtisâren yeniden tertib olunarak (Hülâsa-i Rehnümâ-yı Fârisî ) isim ve ünvanıyla tevsîm kılındı."

34 Bu eserini Hacı Mirza Hüseyin Şerif’e ithaf eder. Mustafa Çiçekler, “Tanzimat sonrası Türkiye'de Farsça", Name-i Aşina, 15-16, (Ankara 2004), s. 94.

35 Düsturce'nin Kasbar Matbaası'nda 1313 yılında yapılan dördüncü baskısının kapağında "Daruşşafaka-i İslâmiye'de tedris olunmak üzere (Heyet-i Tedrisiyye-i İslâmiyye) tarafından intihab ve kabul olunduğu" yazılıdır.

36 Alparslan, "Habib Efendi", s. 370-371. 
mahsus Berg-i Sebz ve Müntehabat-ı Gülistan, Daruşşafaka için hazırlanan ders kitaplarıdır. Ali Alparslan'ın Habib Efendi biyografisinde Müntehabât-ı Ubeyd-i Zâkanî (İstanbul 1303) de ders kitabı mahiyetindeki eserleri arasında zikredilmektedir. $^{37}$

Devlet desteğiyle giriştiği ders kitabı yazma tecrübesiyle Mirza Habib İsfehanî, Osmanlı'da Farsça gramer yazıcılığının önderi olmuş ve kendisinden sonra çeşitli düzeylerde yazılan Farsça ders kitaplarını da üslub ve yazıcılık noktasında etkilemiştir. ${ }^{38}$ Zira Habib Efendi, Farsça’nın gramerini Arapça usulden ayrı olarak ele alıp Farsça gramer kitaplarının tertib ve muhtevasını Arapça eserlerin tercüme ve taklidinden kurtaran ilk kişidir. Ona göre birçok Arapça gramer kitabı vardır; ancak günümüz insanlarına eski usulde bu dilin öğretimi son derece zordur. Kendisinin hazırladığı Destur-ı Suhan adlı kitapla Farsça kısa sürede, hızlı ve kolay bir şekilde öğrenilebilecektir. Aynı zamanda bu eser, Fars dilinin kaidelerini anlatan kitaplar içinde "destur" kelimesini isim olarak kullanan ilk kitaptır. $^{39}$

37 Türkiyéde Basılmış Farş̧a Eserler Çeviriler ve Irranla İlgili Yayınlar Bibliyografyası'nda bu eser Müntehab-ı Letaif, İstanbul 1303 Matbaa-i Ebüzziya Tevfik, 129 s. kaydıyla zikredilmiştir. Ancak bu kayıtta Mirza Habib Efendi'nin eserle herhangi bir bağlantısı kurulmamıştır. Türkiye'de Basılmış Farş̧a Eserler Çeviriler ve İranla İlgili Yayınlar Bibliyografyası, (Ankara 1971), s. 80. DİA'daki Ubeyd-i Zâkânî maddesinde Ubeyd-i Zakanî külliyyâtından "Ahlâku'l-eşrâf, Rîşnâme, Sad Pend, Risâle-i Dilgüşâ, Risâle-i Tarîfât, Mellâd u Piyâz ve bazı şiirler” in Fransa’nın İstanbul başkonsolosu M. Ferténin mukaddimesiyle Mirza Habib Efendi tarafından Müntehab-1 Letâif (İstanbul 1303) adıyla neşredildiği kayıtlıdır. Hasan Çiftçi, "Ubeyd-i Zakani”, DİA, 2012, XLII, s. 16. Ancak söz konusu kitap incelendiğinde mukaddimenin altında mütercim Ferte'nin imzası olduğu görülmüş ve kitabın Mirza Habib Efendi ile herhangi bir bağlantısı olduğuna dair bir kayda rastlanamamıştır. Aynı maddede Zâkânı̂nnin Osmanlı divan şairleri ve Tanzimat devri yazarlarınca takdir edildiğine vurgu yapılıp Ebüzziya Mehmed Tevfik'in Zâkânînnin sözlerinden seçmeler yaparak bunları Türkçeye çevirdiği (Müntehabât-ı Letâif, İstanbul 1303) de kaydedilmiştir. Kanaatimizce iki ayrı kitap olarak kaydedilen kitaplar aynı kitaptır. Madde yazarının doktora çalışmasında ise eser şu şekilde zikredilmiştir: "Zakani’nin mizah türündeki risalelerinin büyük kısmı Letâyif-i Ubeyd-i Zâkânî adıyla ilk kez bir arada İstanbul (Ferthe tarafından Ebuzziya Tevfik matbaasında 1886/1303)'da neşredilmiştir. Başında zamanın Fransa İstanbul Başkonsolosu Ferthe ve Mirza Habib İsfehanî’nin birer mukaddimesi de bulunmaktadır.” Hasan Çiftçi, "Ubeyd-i Zâkânî Toplumsal Görüşleri, Ahlak ve Felsefesi”, (Doktora tezi), Atatürk Üniversitesi, 1996, s. 48.

38 Osmanlı'daki Farsça ders kitapları ve Mirza Habib’in bu kitapların yazarları üzerindeki etkisi için bkz. Riyâhî, s. 250-256; Mirza Habib'in Tanzimat sonrası Türkiye'de Farsça eğitimindeki yeri için ayrıca bkz. Çiçekler, s. 91-95.

39 Çiçekler, s. 92. 
En önemli Türkçe eseri İstanbul'da 1305/1888 yılında basılan Hat ve Hattatan'dır. ${ }^{40}$ İranlı ve Türk hattatların biyografileriyle hat sanatına dair çeşitli bilgi ve metinlerden meydana gelen eserin sonunda ayrıca bazı meşhur müzehhip ve mücellitler hakkında bilgi vermiştir. Haklarında bilgi verdiği kişilere dair Arapça, Farsça ve Türkçe şiirlerle zenginleştirilmiş olan eserin bir özelliği de İbnü’lBevvâb'in hatla ilgili Arapça el-Kasîdetür-râiyye’sinin metni ve Türkçe şerhiyle (s. 45-47), Muhammed b. Hasan es-Sincârî̀nin Bidatül-mücevvid fî ilmi'l-hat ve usûlih adlı 135 beyitlik Arapça manzum risâlesini (s. 278-285) ihtiva etmesidir. Hat ve Hattâtân'ın baş tarafında hattın ortaya çıkışı, gelişmesi, özellikle Arap hattının menşei ve çeşitleri anlatılmış, bu sanata hizmet ederek onu geliştiren üstatların şeceresi verilmiştir. Eserin iki bölümden meydana gelen biyografi kısmı İran ve Osmanlı hattatlarına ayrılmış, ilk bölümde bilhassa ta lik, ikinci bölümde sülüs ve nesih yazan hattatlara geniş yer verilmiştir. Ancak Osmanlı hattatlarıyla ilgili bilgilerde yer yer yanlışlıklar vardır. ${ }^{41}$

Molier'in Le misanthrope adlı piyesini Terceme-i Misantrope (Guzâriş-i Merdümkiriz) (İstanbul 1286 Tasfir-i Efkar Matbaası) adıyla tercüme etmiştir. ${ }^{42}$ James Morier'in Aventures d'Hajji Baba d'Ispahan adlı romanını Hacı Baba-yı İsfehanî (Kalküta 1905) ${ }^{43}$ adıyla basmıştır. 1883'te yayınladığı Çehârgâh ile 1888'de yayınladığı Yernâme adlı manzumelerini İstanbul'da gizlice bastırmıştır. ${ }^{44}$ Rifâa et-Tahtâvî̀nin G. Depping'den çevirdiği Kalẩidüll-mefâhir fì garîbi avâidil-evâil ve'l-evâhir adlı eserini Garâib-i Avâid-i Milel adıyla Farsçàya tercüme ederek 1303 'te İstanbul'daki Ahter Matbaası'nda bastırmıştır. Nispeten ilmi değeri olan ve tashih edip lugat eklediği Ebû İshak Hallâc Şîrâzînnin Dîvân-ı Et 'ime-i Bishak (İstanbul 1302) ile yine mukaddime ekleyerek yayınladığı ${ }^{45}$

$40 \mathrm{Bu}$ eseri E. G. Brown'un İran Edebiyatı Tarihi ile ilgili çalışmasında da zikredilmiştir. Brown, Literary History of Persia (1500-1924), (Cambridge: Cambridge University 1930), s. 450.

41 Alparslan, "Habib Efendi”, s. 370-371. İbnülemin de Suyolcuzade ve Müstakimzade’nin eserlerinden ve diğer eserlerden özetlenerek yazılan oldukça faydalı bu eserin kendi zamanına ait kısmı muhtasar olduğu ve araştırmadan yazıldığı için barındırdığı yanlışlardan dolayı eleştirmiştir. İnal, s. 475.

42 Brown, s. 459; Söz konusu tercüme Osmanlıca basılan ilk eseridir. Niya, s. 499.

43 A. Alparslan, s. 371. Hacı Baba-yı İsfehanî hakkında bir değerlendirme için bkz. Şerifî, "Sergüzeşt-i Hacı Baba-yı İsfehanî”, Danişnâme-i Edeb-i Fârisî/6, Edeb-i Fârisî der Anadolu ve Balkan, (Tahran 1383), s. 437-440; Bu kitabın Kalküta’da ruhsatsız olarak 10.000 adet basıldığına dair bkz. İnal, s. 474.

44 Şerifî, "Habib İ́sfehanî”, s. 316.

45 "Kari, Mahmud Nizam Kezdî: Divân-ı Elbise. Mukaddime: Habib İsfehanî (İstanbul: Ebuzziya Matbaası, 1303), 207.” Türkiye’de Basılmı̧s Farş̧a Eserler Çeviriler ve İranla İlgili Yayınlar Bibliyografyasi, (Ankara 1971), s. 61. 
Nizâmeddin Mahmud Karînnin Dîvân-ı Elbise’si (İstanbul 1303) araştırmaya dönük çalışmalarıdır. ${ }^{46}$ Bunlara ilaveten yazdığı Manzum Farsça Mevlid-i Nebevi ve 60 beyitten oluşan Tarih-i Al-i Osman ile Jil Pılas [Gil Blas]'in Farsça tercümesi basılmıştır. ${ }^{47}$ Ayrıca Ayasofya Camii Enderun Kütüphanesi'nin fihristini hazırladığı da kayıtlara geçmiştir. ${ }^{48}$ Bir sayfa bile olmayan sınırlı biyografisini ve seçilmiş şiirlerini kendi el yazısı ile yazdığı mecmua ve müntehabat-ı asar-1 meşahiri içeren diğer mecmuaları İstanbul Üniversitesi, Nadir Eserler Kütübhanesi'ndedir. ${ }^{49}$ Kütüphanedeki evrakı ziyaret eden İran sefiri Han Melik Sasani,

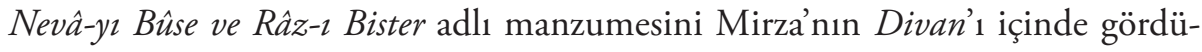
günden bahsetmektedir. ${ }^{50}$

Şiir ve kasidelerini yayınladığı Ahter, eserlerinin büyük bir kısmını da tefrika ettiği mecra olmuştur. ${ }^{51} \mathrm{Bu}$ minvalde Ahter' in Mirza'nın eserlerinin ortaya çımasında özel bir yeri olduğu muhakkaktır. İlk şiirlerinde mahlasını zikrederken son şiirlerinde mahlas kullanmaktan vazgeçtiğini otobiyografisinde ifade etmiştir. ${ }^{52}$

46 Mirza Habib İsfehanînnin entelektüel biyografisi açısından Düstur-ı Suhan, Divan-ı Etime ve Divan-ı Elbise çalışmaları kendisinden Farsça okuyan Avrupalılarla ilişkilerinin bir sonucu ve o dönemin Osmanlı muhitinde mevcut olan yenileşme hareketinin bir işareti olarak da okunmaktadır. Riyâhî, s. 267; 4 günde kendi el yazısı ile istinsah ettiği Divan-ı Elbise nüshası metrukatı içerisinde bulunmaktadır. Bu nüsha için bkz. Nizam el-Kari, Divan-ı Elbise, İstanbul Üniversitesi Nadir Eserler Kütüphanesi, no. FY 310.

47 İnal, s. 474; Nevsal-i Servet-i Fünûn'da yer alan biyografisinde Türkçe ve Farsça şiir mecmuası ile Jil Blas'ın Farsça'ya tercüme ettiği bir eseri, basılmamış eserleri arasında zikredilmiştir. Nevsal-i Servet-i Fünun, s. 85; Basılmamış bu nüsha için bkz. Losaz Fransevi, Tercüme-i Zeyl-i Bilas (Tercüme-i Jil Bilas), (mütercim Habib İsfehani) İstanbul Üniversitesi Nadir Eserler Kütüphanesi, no. FY 294; Sergüzeşt-i Jil Blas adlı romanın Mirza Habib İsfehani'ye nisbeti hakkındaki tartışma için bkz. Şerifî, "Sergüzeşt-i Jil Blas", Danişnâme-i Edeb-i Fârisî//6, Edeb-i Fârisî der Anadolu ve Balkan, (Tahran 1383), s. 440-441.

48 Şerifî, "Habib İsfehanî”, s. 316.

49 İnal, s. 474. Bu kayıtta Mirza’nın metrukatının Kütüphane-i Umumi’de olduğu işaret edildiğinden öncelikle söz konusu eserleri Beyazıt Devlet Kütüphanesi Nadir Eserler kısmında aradık ve fakat bulamadık. Bu eserlere İ. Ü. Nadir Eserler Kütüphanesi Farsça Yazma Eserler bölümünde tesadüfen rastladık. Mirza Habib’in Nadir Eserler Kütüphanesi'ndeki bütün eserleri, Rıza Paşa koleksiyonu bağışı olarak kayıtlıdır. Bu durumun tek istisnası ise Habib İsfehani’nin Talik hattı ve müellif eliyle yazılan FY 712 numaradaki "Mecmua-i Eş’ar ve Fevaid” adlı eseridir. Bu eser Halis Efendi Kütüphanesi koleksiyonundan Nadir Eserler’e bağışlanmış görünmektedir.

50 Şerifî, "Habib İsfehanî”, s. 317.

51 Niya, s. 499-500, 513.

52 Başlarda "Destan” mahlasını kullanmıştır. Bkz. Habib İsfehani, Mecmua-i Eş̧ar ve Fevaid, İstanbul Üniversitesi Nadir Eserler Kütüphanesi, no. F 712. 
İbnülemin'in ifadesiyle "Türkçe nazımları Acemce nazımları derecesinde değildir, biraz acemicedir". 53

\section{Mirza Habib İsfehani'nin Metrukatı}

Tophane'deki Defterdar Ebu'l-fazl mahallesinde ikamet eden Habib Efendi, 1 Mayıs 1309/13 Mayıs 1893'te Bursa'da vefat ettiğinde, varisleri büyük oğlu Mehmed Kemal, eşi İkbal Hanım ile diğer çocukları Mehmed Cemal ve Ahmed Celal Beylerdi. Terekenin düzenlenmesi, eşyaların satış işlemlerinin gerçekleşip mirasın taksim edilmesi; Habib Efendi'nin vefatından kısa bir süre sonra tamamlanmıştır. Terekenin sonundaki 2 Temmuz 1893 tarihi, Mirza Habib’in vefatından bir buçuk ay gibi kısa bir sürede düzenlendiğine işaret etmektedir. Eşya ve kitapların satıldığı 3 Eylül 1893 tarihi ise miras işlerinin vefatından 3,5 ay sonra tamamlandığı ve varislere haklarının teslim edildiğini göstermektedir. Esasen bu kadar hızlı miras taksimi yapılmasının sebebi; Mirza’nın ardında bıraktığı iki küçük çocuğun hakkının gözetilmesi için Kadı'nın terekeye hemen el koyması olmalıdır. ${ }^{54}$ Ayrıca Mirza’nın herhangi bir gayrımenkulünün ve alacak-verecek kabilinden borç ilişkilerinin olmaması da terekenin hızla taksim edilmesini kolaylaştırmış görünmektedir.

İstanbul'a geldiği andan itibaren hem özel dersler verip hem de devlet okullarında hocalık yaparak iaşesini temin eden Habib Efendi, memuriyetinin son on beş yılında Maarif Nezareti Encümen azalığı yapmıştır. Miras hesaplamaları yapılırken Darüşşafaka ve diğer Maarif birimlerinden maaş alacakları tahsil edilmiştir. Habib Efendi'nin miras olarak büyük miktarda nakit para ve eşya bıraktığı görülmüş ancak gayrımenkul kaydına rastlanmamıştır. Miras taksimatı iki aşamalı gerçekleşmiş, ilk önce nakit para daha sonra da eşyaların satışından elde edilen gelir varislere paylaştırılmıştır.

53 İnal, s. 474.

54 Kanuna göre, varisler arasında yetim, gaib, mefkud ve mecnun gibi reşit olmayan kişilerin bulunması durumunda kadılar talep olmaksızın mirasa müdahale edeceklerdir. Toplumun himayeye muhtaç kesimlerini korumayı hedefleyen kanunun uygulanmasına her dönemde özen gösterildiği rahatlıkla ifade edilebilir. Belgelerde 'tahriri mucib' tabir edilen bu grup terekeler ve diğer terekeler ile Osmanlıların miras paylaşımını niçin mahkemeye taşıdıkları ve miras konusunda hukuki yolları kullanma eğilimleri hakkında ayrıntılı bilgi için bkz. Fatih Bozkurt, "Tereke Defterleri ve Osmanlı Maddi Kültüründe Değişim (1785-1875 İstanbul Örneği)” (Doktora tezi, Sakarya Üniversitesi, 2011). 
Habib Efendi'nin mirasının \%63'ünü bankadaki nakit parası, \%29'unu kitaplarının satışından elde edilen gelir ve $\% 8$ 'ini de şahsi eşyalarının satışından elde edilen gelir oluşturmaktadır. ${ }^{55}$ Banka hesabındaki yaklaşık 55.000 kuruşluk nakit, dönemi için ciddi bir servete tekabül etmekteydi.

Habib Efendi'nin Encümen azalığı maaşına 5 Teşrin-i sani 1302/ 17 Kasım 1886 'da yapilan 135 kuruşluk zamla birlikte 1335 kuruşa çıkan maaş1 ${ }^{56}$ vefat ettiği tarihe kadar sabit kalmıştır. ${ }^{57}$ Carter V. Findley’in Osmanlı memurlarının toplumsal tarihini incelediği çalışmasında, 1890'larda bir Osmanlı memurunun aylık ortalama 1000 kuruş maaş ile rahat geçindiği kaydedilmiştir. ${ }^{58}$ Şu durumda Habib Efendi, tipik bir Osmanlı kalemiye mensubu kadar maaş almış ve ailesini geçindirmiştir.

Tereke kaydına göre Kredi Lyon Bankası'nda [Banque Crédit Lyonnais] hesabı olan Habib Efendi'nin vefat ettiğinde Maarif Nezareti'nden ve Darüşşafaka'daki muallimlik maaşı hesabından birikmiş alacakları mevcuttu. ${ }^{59}$ Mahkeme payları düşüldükten sonra kalan 52.636 kuruşluk nakit parası, eşyalarının satışından elde edilen 7.285 kuruş $^{60}$ ve kitaplarının satışından elde edilen 24.787 kuruşluk gelire, biriken maaşları ve büyük oğlundaki nakdi de eklendiğinde elde edilen miktardan, mahkeme kaydı, dellaliye parası, harç pulu gibi masraflar düşülerek hesaplama yapılmıştır. Mirastan İkbal Hanım’a 11.368 kuruş, çocukları Mehmed Celal ve Ahmed Celal Beylere 24.851,5'er kuruş, Mehmed Kemal Bey'e ise kardeşlerinden biraz daha fazla 26.525,5 kuruşluk bir hisse düşmüştür. Netice itibariyle Mirza Habib'in 19. yüzyılın sonlarında, İstanbul'un zenginleri arasında

$55 \mathrm{Bu}$ hesaplama mahkeme kayıt ücreti, dellaliye masrafı ve harç pulu gibi rutin masraflar düşüldükten sonra elde edilen miktar üzerinden yapılmıştır.

56 BOA, MF MKT 145/132, 29 Zilhicce 1309/25 Temmuz 1892.

57 BOA, Babıali Evrak Odası (Bundan sonra BEO) 207/15458, 08 Zilkaade 1310/24 Mayıs 1893.

58 Carter V. Findley, Kalemiyeden Mülkiyeye, çev. Gül Çağalı Güven, İstanbul: Tarih Vakfı Yurt Yayınları 1996, s. 347.

59 Osmanlı bürokrasisinde 1838'de başlatılan maaş sistemi ve geciken, biriken memur maaşları hakkında ayrıntılı bilgiler veren Carter V. Findley, Sadrazam Hayreddin Paşa’nın terekesi örneğinden hareketle "gecikmiş maaş ödemeleri vefat eden kişinin terekesinde sayılabilecek kadar büyük olabiliyordu” ifadelerini kullanmıştır. Findley, s. 324. Makaleye konu olan Encümen azası Habib Efendi'nin terekesindeki maaş alacakları, bu kanaati doğrulamakla birlikte artık sıradan bir memurun terekesinde de maaş alacaklarının belirtilmesi, "gecikmiş maaş"ın normalleşen bir olguya dönüştüğ̈̈ne işaret etmektedir.

60 Terekede yazılan rakam esas alınmıştır. 
sayılabilecek neredeyse 90.000 kuruşluk hatırı sayılır bir servet bıraktığı rahatlıkla söylenebilir. ${ }^{61}$

\section{Yüzyıl İstanbulu'nda Bir Acemin Hanesi: Mirza Habib Ne Giyer, Nasıl Bir Evde Yaşardı?}

Habib Efendi'nin satılan şahsi eşyalarının listesi, yaşam standardı hakkında bazı ipuçları verdiği gibi zevkleri ve tercihlerini de anlamayı sağlayacak bir takım bilgileri içermektedir. Çünkü bu eşyalar XIX. yüzyılın sonlarında İstanbul'da yaşayan bir İranlı'nın gündelik hayatta ne giyip kuşandığından, evinde otururken, çalışırken ya da uyurken ne tür eşyalar kullandığına, evini nasıl tefriş ettiğine hatta mutfağında neler kullandığına dair zengin bir malzeme sunmaktadır.

Mirza hem Osmanlı kalemiye sınıfına mensup bir memura hem de Osmanlı kibar muhitlerine yaraşır biçimde gardrobunda epeyce takım elbise ve kıyafet bulundurmaktadır. 4'ü kırmızı renkte olmak üzere 7 adet pantalonu; ikisi çukadan olmak üzere 8 yeleği; 4’ü Avrupâ̂, 6'sı beyaz olmak üzere 10 gömleği; çukadan 1 adet redingot ile 1 adet setresi ve 2 de kumaşı belirtilmeyen setresi ile toplam 5 adet uzun ceketini kalemdeki görevine ya da okullardaki muallimlik vazifesine giderken giyiyor olmalıydı. Eğer bu takım elbiselik kıyafetler, mevsimlere göre yazlık ve kışlık diye ayrılmıyorsa neredeyse haftanın her günü farklı bir takım elbise giyebilecek evsafta bir dolapla karşı karşıyayız. Havanın soğuk günlerinde kullandığı 3 paltosundan biri kırmızı renkli diğeri kastor denilen kürkten imal edilmişti. Yine kastor kaputu, sakoya kaplı samur kürkü ve çukaya kaplı köhne cild kafa kürkü onu soğuktan korumaya yarayan dış kıyafetleriydi. Serin günlerde ise pardesüsü ile bütün vücudu örten uzun ve kolsuz bir üstlük olan maşlahını kullanıyordu. Her ne kadar modern takım elbiseler giyse de terekedeki İrankâri maşlah kaydı, İranî zevklerini devam ettirdiğini ve kimliği ile uyumlu üst kıyafet tercihlerinde bulunduğunu gösterir. Samur kürkler ve kastor kaputlar varlıklı kimselerin gardroplarında eksik olmayan kıyafetler olduğuna göre Mirza’yı gündelik kıyafetleri itibariyle yaşam standardı yüksek biri olarak değerlendirmek gerekir. Yine pahalı ve kıymetli saatler taşıyor olması hem varlıklı hem de zevk sahibi birisi olduğunun ispatıydı.

61 İstanbul terekelerinden Osmanlı'da maddi kültür değişimini ele alan Fatih Bozkurt, tezinin servet dağılımını incelediği bölümünde 1873-74 yıllarında 15.000 kuruşun üstünde serveti olanları zengin kategorisinde değerlendirmiştir. Bozkurt, s. 102. 
Mirza'nın gardrobunda dış kıyafetler bakımından görünen zenginlik ev kıyafetlerinde de kendini göstermektedir. 2 fanila gömleğini, evde halı dışındaki yerlere basmak için kullandığı bir çift terliğini, belki de gecelik olarak kullandığ 2 entarisini, uyurken ya da evde otururken kullandığı 1 başlığını, 3’ü renkli olmak üzere 4 hırkasını, 3'ü İrankârî olmak üzere 4 çift çorabını, iç çamaşırı olarak kullandığı 11 adet donunu evindeki 2 köhne sepet sandığa koyarak ya da 2 bohçaya sararak muhafaza etmekteydi. Elbette Mirza'nın evinde bahsedilen bohçalar ve sepet sandık ${ }^{62}$ dışında kıyafetleri, yatak takımlarını ya da evde kullanılan gündelik eşyaları saklamak için başka mahfazalar da vardı. İşte Mirza’nın metrukatı arasında görülen "harar" 63 bunlardan biriydi. Yazı takımlarını belki de kıymetli saatlerini muhafaza ettiği bir adet abanoz çekmece de mahfazalar arasında sayılabilir. 45 kuruş ile terekede yerini alan abanoz çekmecenin fiyatı sanatlı ve kıymetli bir çekmece olduğunu düşündürmektedir.

Eskiden konak ve hanelerde bulunan aynalar, en önemli tezyinattan biri idi. Hanımlar aynaların yardımıyla giyinip süslendikleri gibi, erkeklerde sarık sarmak, sarığı düzeltmek, elbiselerinin arkadan duruşlarını gözden geçirmek için aynaya ihtiyaç duyarlardı. Ayrıca büyük ve müzeyyen aynalar sahibinin kudret ve zenginlik derecesini gösterdiği gibi itibarını da arttırırdı. ${ }^{64}$ Mirza gibi gardrobu zengin birisinin de evinde bir aynasının olması çok tabiidir. Nitekim terekesinde büyüklük ya da sanatlı olup olmadıklarına dair bilgi verilmeyen 2 ayna kaydı yer almıştır. Aynalar dışında yaz sıcaklarında serinlemek için kullandığı 3 adet yelpazesi de terekede dikkat çeken eşyalardandır.

72 kuruş değerindeki 4 İrankâri pencere perdesi, 54 kuruş değerindeki 8 pencere perdesi, 15 kuruş değerindeki İrankâri pencere perdesi ile fiyatı belli olmamakla birlikte 5 perde $^{65}$, yine fiyatı belli olamayan ancak diğerleri kadar pahalı

62 Dışı sepet örülerek meşin kaplanmış bir sandık türüdür. Abdülaziz Bey, Osmanlı Âdet, Merasim ve Tabirleri, haz. Prof. Dr. Kâzım Arısan, Duygu Arısan Günay, (İstanbul: Tarih Vakfı Yurt Yayınları 1995), I, s. 200.

63 "Bir evden diğerine taşınırken içine yatak takımları basılan ve aşağıdan yukarıya kadar deriden, yukarısı kıl, çuvaldan büyük geniş hararlar...” Abdülaziz Bey, Osmanlı Âdet, s. 200.

64 Abdülaziz Bey, Osmanlı Âdet, s. 206.

65 Terekede bir odanın tefrişatında kullanıldığı anlaşılan eşyaların fiyatların toplam bedelinin kaydedildiği görülmektedir. Bu eşyalar arasında yer alan 5 pencere perdesinin birim fiyatı belli olmamakla beraber odadaki 2 ot dolu minder, 1 şilte, 1 ihram makad, 7 yastık, 2 yüz yastığı, 7 gaz lambası, 3 sürahi, 2 bardak, 2 saksı, 3 sandalye ve 1 de ayna ile birlikte 300 kuruş değerinde oldukları kayıtlıdır. 
olmadığı anlaşılan 4 pencere perdesi ${ }^{66}$ büyük ve ferah bir evde belki de iki katlı bir konakta oturduğunu düşündürmektedir. Pencere perdeleri hane mahremiyetini dışarı karşı sağlarken terekede 28 kuruş fiyatı ile kaydedilen kapı perdesi ise hane içinde oda mahremiyetini temin ediyor olmalıydı.

Alafranga beslenme kültürünün önemli araç-gereçlerinden olan çatal-bıçak ikilisi, XIX. yüzyılın üçüncü çeyreğinden itibaren müslüman Osmanlı elitinin evlerinde de iyiden iyiye görülmeye başlamıştı. ${ }^{67}$ Mirza’nın evindeki sofra düzenin bir parçası olduğu anlaşılan çatal-bıçak ikilisi, sadece yabancı misafirleri ağırlarken bulunduğu kutudan veya çekmeceden çıkarılıyor olamazdı. 10 adet maden kaşık, 8 adet çatal, 10 adet bıçak ve "10 kaşık ma' hırdavat" şeklinde terekeye yansıyan servis takımlarının nicel verileri, Şarka mahsus üretimler olduğunu düşündürmektedir. ${ }^{68}$ Çünkü batıya mahsus servis takımlarında 12 adet, doğuya mahsus "düzine" de 9-10 adet olurdu. Alafranga servis takımlarına sahip olsa da yemeklerini masa yerine yer sofrasında yemeyi tercih ettiğini düşünmemize sebep, terekesinde herhangi bir masa kaydı bulunmamasıdır. Mirza’nın satılan eşyaları arasındaki 6 adet hezârâne [renkli?] sandalyenin bir takım olduğu ve masa etrafında kullanıldığı ilk akla gelen ihtimal olsa da terekede masa kaydının olmaması, bu renkli sandalyelerin terekedeki diğer sandalyeler gibi müstakil kullanıldığını düşündürmektedir. Terekedeki 1 adet tahta sandalye ile herhangi bir özelliği belirtilmeyen 3 sandalye de Mirza'nın evinde farklı amaçlarla kullanılıyor olmalıydı.

Alafranga kültüre açık birisi de olsa Mirza, ev eşyası tercihlerinde büyük oranda Şarklılığını muhafaza etmiştir. Birisi 6 yan yastık diğeri 7 yan yastıkla beslenen makadlar evin iki odasının ana oturma aksamını oluşturmaktadır. İstanbul'daki birçok müslüman hanesinde olduğu gibi Mirza’nın evinde de bu makadların üzerine ihram adı verilen örtüler serilir, şiltelerde ve minderlerde oturulurdu. Terekesinde hem yatmaya hem de üzerine oturmaya yarayan 7 şiltenin 3'ü pembe

66 Tereke katipleri genelde her eşyayı tek tek kaydederken bazen kolaylık olsun diye eşya grupları oluşturup eşyaları tek tek fiyatlarını ise toplam olarak kaydederlerdi. İşte böyle bir eşya grubu arasında yer alan 4 pencere perdesinin birim fiyatı belli olmamakla beraber odadaki 2 minder, 6 yastık ve 1 makadın da dahil olduğu eşya grubunun 40 kuruş değerinde oldukları kayıtlıdır.

67 Bu konuda ayrıntılı bilgi için bkz. Fatih Bozkurt, "Sofrada Çatal-Bıçak Kullanımı yahut Osmanlı Sofra Âdâbının Değişimi”, Kültürümüzde Adab-ı Muaşeret, haz. Azmi Özcan (Bilecik Şeyh Edebali Üniversitesi, 2015), s. 27-37.

68 Feketenin 16. yüzyılda bir Türk efendisinin evini anlattığı çalışmasında batıya mahsus servis takımlarının 12 adet, doğuya mahsus "düzine” de 9-10 adet olduğunu ifade etmiştir. Fekete Lajos, "XVI. Yüzyılda Taşralı Bir Türk Efendi Evi”, çev. M. Tayyip Gökbilgin, Belleten, XLIII/170, Türk Tarih Kurumu: Ankara 1979, s. 470. 
renkli, biri tüylü şilte olarak kayıtlara geçmiştir. Yine terekede bir kısmı otla doldurulmuş 9 minder ile 3 tane erkan minderi kaydı Mirza’nın evindeki oturma düzeninin mobilyalar değil de doğuya mahsus oturma eşyalarıyla sağlandığını gösterir. Mirza Habib'in yatak odasında yer yatağı kullanması, Şarka mahsus eşya tercihini sürdürdügünü göstermektedir. Terekedeki 1 yün döşek dışında yer alan 7 şilteden kaç tanesinin yatak olarak kullanıldığını bilemesek de 5'i renkli, 3’ü İrankârî olan yorganları, başta Mirza olmak üzere hane halkının diğer üyeleri de geceleri kullanıyor olmalıydı. Yorgan sayısına bakıldığında Mirza Habib’in beş kişilik hanesindeki dokuz yorganın bir kısmının misafirler için ayrıldığını ve misafir yorganı olarak kullanıldığını düşünmek yanlış olmaz.

Terekede 1 adet şamdan kaydının yanında 7 adet gaz lambası kaydedilmesi, Mirza Habib'in ev aydınlatmasında mumdan ziyade gaz lambası tercih ettiğini göstermektedir. Bu gaz lambalarından en azından biri, Mirza ertesi gün vereceği derse çalışırken, bir sonraki Ahter nüshası için makale hazırlarken, kitap telif ederken ya da tercüme yaparken yanıyor olmalıydı. Diğer lambalar akşam yemeğine çağrılan misafirleri ağırlarken misafir odasında, hane halkı ile gece sohbetleri yaparken oturma odasında, yer yatakları sererken yatak odalarında bazen de akşam kahveleri hazırlanırken mutfakta kullanılıyor olmalıydı.

Mirza’nın evinde kışları ısınmak için kullandıkları sarı mangal, Osmanlı kibar muhitlerinde tercih edilen Süleymaniye işi veya Selanik mamulatı sarı mangallardan biri olabilirdi. ${ }^{69} 300$ kuruş fiyatıyla kaydedilen bu sarı mangal, terekedeki 800 kuruşluk tepegöz altın saat, 470 kuruşluk Şarkköy kilimi, 451 kuruşluk çalar altın koyun saatinin ardından en pahalı dördüncü ev eşyasıdır. Osmanlı hanelerinde kullanılması pek tabii ve zaruri sayılabilecek eşyalardan biri olan seccadelerin birçok türü vardır. İşte muhterem misafirlere serilmek üzere evlerde bulundurulan zarif ve sanatlı seccadelerden biri de Kırşehir seccadesiydi $^{70}$ ki Mirza Habib'in eşyaları arasında bir adet mevcuttu. 179 kuruşluk değeri ile evdeki lüks eşyalar arasında sayılabilecek Kırşehir seccadesi saygın misafirlere çıkarılırken hane halkı namaz kılarken daha mütevazi olan postu kullanıyor olmalıydı.

Abdülaziz Bey, Osmanlı konaklarında kısa sedir üzerine ipek yüzlü bir minder, önüne konmuş rahle, gerektiğinde yakmak için bir çift kısa bronz şamdan,

69 Abdülaziz Bey, Osmanlı Âdet, I, 164; Konaklardaki vazifelilerden biri olan kitapçı efendi hakkında ayrıntılı bilgi için bkz. aynı eser, s. 175-176.

70 Abdülaziz Bey, Osmanlı Âdet, s. 198-199. 
bir yazı takımı, yerde kitapçı efendiye mahsus bulunan minder ve duvar önlerindeki camlı dolaplarda ev sahibinin şahsi malı olan nefis kitapların oluşturduğu kütüphane odalarından bahseder. ${ }^{71}$ Mirza'nın terekesinde yer alan 2 hokka, 1 devat ve 1 rihdandan oluşan 39 kuruşluk yazı takımı, 162 kuruş değerindeki camlı kütüphane, 56 kuruşluk kitap rafı ile minderler Osmanlı konaklarındaki kütüphane odalarından farksız bir odayı gözümüzde canlandırıyor. Mirza'nın 1 adet yazıhanesi ve 24 kuruş değerindeki küresinin de kütüphane odası eşyaları arasına girmesi, Osmanlı konaklarındaki sıradan bir kütüphane odası aksamından daha gösterişli bir kütüphane odası ile karşı karşıya olduğumuzu düşündürmektedir.

"Hem hoş hem de kibarâne bir eğlence olan” satranç oyununa Mirza Habib de düşkün olmalıydı ki evinde bir satranç takımı bulundurmaktaydı. Satranç dışındaki zevklerinin başında herhalde kıymetli saatlere sahip olmak gelmektedir. Çünkü terekesi küçük çapta koleksiyon oluşturacak evsafta saate sahip olduğunu kanıtlamaktadır. En kıymetli parçası 874 kuruşluk kordonlu altın saat olan bu koleksiyonda, 800 kuruşluk tepegöz altın saat, 451 kuruşluk çalar altın koyun saati ve 99 kuruşluk gümüş saat de bulunmaktaydı. Osmanlı ahalisi servetlerine, yaşlarına, cüsselerine göre altın, gümüş, savatlı köstekli, kordonlu, kimi neredeyse bir kaplumbağa yavrusu kadar büyük ve tombul, kimi küçük ve yassı bir 'koyun saati' taşımaktan hoşlanıyordu. ${ }^{72}$ Saatin bir prestij ögesi olarak kullanımının yaygın olduğu bir dönemde Mirza’nın altın ve gümüş kıymetli saatleri olması lüks yaşam standartlarına sahip olduğunu bir kez daha gözler önüne sermektedir.

Mirza Habib'in saat ve satranç kadar silah merakı olduğu da anlaşılmaktadır. Terekesindeki 131 kuruş değerindeki revolver takımını 121 kuruşluk bir diğer rovalveri ile 40 kuruşluk cep revolveri takip etmektedir. Silah merakı ya da silaha sahip olma isteği, biyografisinde ayrıntılı biçimde anlatılan İran'dan Osmanlı Devleti'ne sığındığı kaçış hikayesiyle birlikte düşünüldüğünde anlamlı görünmektedir. Habib Efendi'nin metrukâtı arasında dikkati çeken İrankâri eşyalar (yorgan, kilim, perde, maşlah, çorap, sahan) ise Habib Efendi gibi yurdundan uzakta yaşamak zorunda kalan birinin evinde olması yadırganmayacak eşyalardır.

Mirza’nın terekesindeki gündelik eşyaları ile kitaplarının satışı maddi olarak karşılaştırıldığında servetinin büyük kısmını kitaplarının oluşturduğu görülmektedir. Kitaplığın satışından elde edilen meblağ, şahsi eşyaların satışından elde

71 Abdülaziz Bey, Osmanlı Âdet, s. 165.

72 Koyun saatleri hakkında ayrıntılı bilgi için bkz. M. Şinasi Acar, Osmanlida Günlük Yaşam Nesneleri, (İstanbul: Yem Yayın 2011), s. 403-406. 
edilen meblağın neredeyse dört katı büyüklüğündeydi. Şahsi eşyalarının satış fiyat aralığına bakıldığında en yüksek fiyatta 874 kuruş değerindeki kordonlu altın saat yer alırken en düşük fiyatta mutfak araç gereçlerinden 5 kuruşluk bıçağın listede yer aldığı görülmektedir. Yazma kitaplar ile kıymetli hat levhalarının yer aldığı kitaplığının satış fiyatı aralığına bakıldığında ise en yüksek meblağı 3300 kuruşla bir 'talik kıta’nın, en düşük fiyatı ise 8 kuruşla bazı Fransızca kitapçıkların aldığı görülmektedir.

\section{Mirza Habib'in Entelektüel Hazinesi: Bezzazistân-1 Atik’te Satılan Kitaplığı}

Makalenin başında da belirtildiği gibi ünlü sefername yazarı Muhammed Hacı Pirzade'yi Hacı Mirza Hasan Han'la birlikte bir akşam evine davet eden Mirza Habib, sadece güzel bir akşam yemeği değil ardından muhteşem kitaplardan oluşan bir kütüphane ziyafeti de vermiştir. Misafirlerin hayranlıkla izlediği, murakkalar, kitaplar ve eşyalardan oluşan bu zengin koleksiyonun tamamı ya da bir kısmı, Mirza’nın vefatının ardından terekesi dahilinde satışa çıkarılmıştır. Satılan kitaplara bakıldığında esasen şahsi kullanım için biriktirilen bu kitaplığın, dönemine göre zengin sayılabilecek bir koleksiyonu barındırdığı görülmektedir. Mirza Habib'in edebiyatçı kimliğinin doğal bir neticesi olarak; koleksiyon temelde edebiyat, hususen de Fars dili ve edebiyatı eserlerinden müteşekkil bir koleksiyon olarak karşımıza çıkmaktadır. İşte bu koleksiyonun değerli yazmaları başta olmak üzere tüm kitapları Bezzazistân-ı atik'te satışa çıkarılmıştır. ${ }^{73}$ Başkentteki ticari hayatın önemli merkezlerinden Bezzazistân-1 atik'te tereke satış işleminin gerçekleşmesi tesadüf değildir. Bezzazistân özellikle yetim mallarının muhafazasında ve işletilmesinde merkezi bir noktada yer almaktay $\mathrm{d}^{74}$ ve varisleri arasında yetimler bulunan Mirza’nın terekesi de bu sebeple Bezzazistân-1 atik'te satışa

73 Osmanlı üst düzey bürokrat ve memurlarına ait kitap terekelerinin Sahaflar dışında da satılması bahsinde ilk defa bu terekeye işaret eden İsmail E. Erünsal'dır. İsmail E. Erünsal, Osmanlılarda Sahaflık ve Sahaflar, (İstanbul: Timaş Yayınları 2013), s. 308.

74 Mirza'nın terekesindeki ifadeler Osmanlı'da yetimlerin miras hakkının nasıl bir titizlikle korunduğunun ve yetim mallarının satışında Bezzazistan’n önemli bir merkez olduğunu bir kez daha göstermektedir: “. .. akçe vasi-i mumaileyh marifeti ve marifet-i şer’le bir tahta sandığa mevzu'an ve memhûren li-ecli'l-hıfz Bezzazistân-1 atîka emaneten irsâl olunduğu..." Kısmet-i Askeriye Mahkemesi, 1940 numaralı defter, s. 74; Yetim mallarının muhafazası ve işlettirilmesinde Bezzazistan'ın rolü ile bedestende kassamlığa ait veyahut yetimlerin sandıkları için kullanılan özel mekanlar olması hakkında bkz. Bozkurt, s. 216-217. 
çıkarılmıştır. Bu durum Mirza’nın kitaplarının neden Sahaflar çarşısı dışında müzayedeye tabi tutulduğuna da açıklık getirmektedir.

İstanbul'da yaşayan bir XIX. yüzyıl münevverinin terekesindeki kitap rafları ve camlı kütüphane de kütüphanesinin bir parçası olarak addedilip kaydedilmiştir. Yaklaşık çeyrek asırlık bir dönemde oluşturulan bu koleksiyonda; bol miktardaki yazı levhası ile devat, hokka, rıhdan gibi malzemeler ayrıca dikkat çekmektedir. Hat ve Hattatân'ın yazarından beklenebileceği gibi kitaplığında bol miktarda murakkaalar, başta Abadî ve pembe renkli olmak üzere hattatlara mahsus birçok kağıt cinsi bulunmaktadır. Daha çok hat sanatına ilişkin albüm olarak rastlanan murakkalardan terekede ikisi talik hatlı olmak üzere 5 adet ve 2 'kıta' murakka bulunmaktadır. Ayrıca murakka yapılmak üzere kullanılacak bir miktar murakka evrakı da tereke kayıtlarında yer almaktadır. ${ }^{75}$ Mirza'nın kütüphanesinde fiyatları itibariyle içlerinde sanatlı veya oldukça süslü olduklarını düşündüren bazı kitap kapları da dahil toplam 45 tane kitap kabı mevcuttur.

Şiir ve hatta özel merakı olan Habib Efendi’nin kütüphanesinde Ateşgede gibi şuara tezkirelerine rastlamak oldukça sıradandır. Kitaplığın çoğunluğunu $\mathrm{Hafız}$ Divanı, Bostan, Mesnevi-i şerif gibi Fars edebiyatının klasik denebilecek eserleri oluşturmaktadır. Fars edebiyatında belagata dair yazılmış en eski eserlerden biri olan Reşidüddin Vatvat'ın Hadaiku's-sibr'i ya da İran şiir tarihinin ana kaynaklarından biri olan Mecmau'l-Fuseha'yı Mirza Habib İsfehani'nin kütüphane raflarında görmek hiç de şaşırtıcı değildir. Mantıku't-tayr gibi birçok tasavvuf kitabının yer aldığı kütüphanede çeşit çeşit tarih ve ahlak kitapları ile seyahatnameler yer almaktadır. Coğrafyaya meraklı olan Habib Efendi'nin kütüphanesinde bu ilginin nişanesi olarak bir küre de bulunmaktadır. Habib Efendi'nin kütüphanesinde İnşa-i kaymakam gibi kitapların varlığı yazı ve inşa mecmuaları türü ile ilgilendiğini göstermektedir. Eskiden her evde bulunan ve işlemeli kumaş kesesi içinde duvarda asılı duran mushaflar evlerin demirbaşı olarak addedilirdi. Bu mushafların yanı sıra ünlü hattatların elinden çıkma sanatlı mushaflar da vardı ki Mirza’nın kütüphanesinde Yakuti hattıyla yazılmış 995 kuruşluk mushaf ile 395 kuruşluk küçük boy mushaf bunlardan biriydi. Yazma divanların yüksek fiyatlarının yanı sıra tek başına 1500 kuruşa satılan Divan-ı Emir Hüsrev Diblevi ise listedeki en pahalı kitap olarak dikkati çekmektedir.

Farsça muallimliği ve ortaöğretim Farsça ders kitapları hazırlayan bir müellifin elinin altında bulunması gereken Farsça/Türkçe divanlar, Fars edebiyatından

75 Murakkaa ve yapım süreçleri hakkında ayrıntılı bilgi için bkz. Acar, s. 191-194. 
seçme metinler ve sözlüklerden oluşan kütüphane sadece Şark dillerine mahsus değildir. Kitaplıktaki Fransızca neşriyat ve sözlükler, Mirza’nın Batı dillerine özellikle de Fransızca'ya olan ilgisinin nişanesidir. 50 kuruşa satılan Arapçádan Fransızca’ya lugat, 3 ciltlik Fransızca Kamus'un yanı sıra Bianchi sözlügü dikkati çeken diğer bir eserdir. Kitap listesinde Bianchi sözlüğünün dört kere muhtelif ciltlerde kaydedilmesi, sözlüğün fasiküller halinde olduğunu düşündürmektedir. Terekede yer alan birçok Fransızca kitabın adı ya da içeriği ile ilgili herhangi bir tanımlama yapılmadığı için kitaplığın Batı menşeli kitapları muğlak kalmaktadır. ${ }^{76}$ İşte terekedeki Fransız Millet Kütüphane adıyla zikredilen, 20 kuruş değerinde ve 23 adet olarak kayıtlara geçirilen ibare bu duruma güzel bir örnektir. Terekedeki ibareden içeriği tam olarak anlaşılamasa da nüsha çokluğu, Fransız Milli Kütüphanesi kataloğu ya da broşürü gibi birşeyler olabileceği ihtimalini akla getirmektedir. Bu ihtimal doğru kabul edilirse Mirza’nın Fransızca neşriyata ilgisinin boyutları da bir adım öteye götürülebilir.

İstanbul'da ardarda senelerde neşrettiği Divan-ı Et'ime ve Divan-ı Elbisénin orjinal birer nüshası da kitaplığında bulunmaktadır. Şeyh Cemaleddin Ebu İshak (Buşhak) Hallac-1 Şirazi (öl. 1427)'nin büyük şiir üstatlarından sonra, kendisine yazacak birşey kalmadığını düşünerek yiyecekleri tasvir edip, iştahı tahrik eden şiirlerini yazdığı Divan-ı Et ime’de Nizami, Sadi, Hafız gibi ünlü sanatkarların şiirlerini, alaylı, neşeli nazirelerle yemeklere uyarlamışıır. ${ }^{77}$ Mirza Habib'in entelektüel biyografisi açısından Divan-ı Et ime ve Divan-ı Elbise çalışmaları, kendisinden Farsça okuyan/öğrenen Avrupalılarla ilişkilerinin bir sonucu ve o dönemin Osmanlı muhitinde mevcut olan yenileşme hareketinin bir işareti olarak da okunmaktadır. $^{78} 1303$ 'te neşrettiği Müntehabât-ı Ubeyd-i Zakani yi hazırlarken kitaplığındaki Ubeyd Zakani nüshasından yararlandığı şüphesizdir. ${ }^{79}$ Hiciv ve

76 Tereke ya da muhallefat kayıtlarında yabancı dillerde yazılmış kitaplara dair katiplerin tavırları hakkında ayrıntılı bilgi için bkz. Erünsal, s. 326-329.

77 Yemeklerin tasviri, kullandığı yemek ve yemek malzemesi ile ilgili kelimeler, kültür tarihinin yanında Türk mutfağı bakımından da çok önemlidir. Turgut Kut, "1927’ye Kadarki Türk Yemek Kitapları Bibliyografyası", http://www.turkish-cuisine.org/article_details.php?p_id=21\&Paging Index=0\&Pages=Articles, (erişim tarihi: 16.01.2015).

78 Riyâhî, s. 267.

79 İstanbul Üniversitesi yazma eser koleksiyonunda F264 numaralı Külliyât-ı Âsar-ı Ubeyd-i Zakani yazmasının künye bilgileri, Mirza Habib’in ömrünün sonuna kadar Zakani üzerinde çalışmaya devam ettiğini düşündürmektedir. Kütüphane künye kaydına güvenecek olursak; bu nüshayı bizzat kendisi çoğaltmıştır. "Mirza Habib İsfehani istinsahlı" nüshanın tarihinin 1308 olması, 1309'da vefat eden Mirza’nın son günlerini bu eserle meşgul olarak geçirdiğini göstermektedir. 
mizah alanında klasik Fars edebiyatının en önemli simalarından olan Ubeyd-i Zâkânı̂dden seçme metinleri hazırladığı orjinal kitap, terekesinde 145 kuruşa satılmıştır. Bunların yanısıra 32 adet Debistan-ı Farisi, 32 adet Mizantrope Tercümesi ya da 72 adet Berg-i Sebz gibi kendi hazırladığı veya telif ettiği kitapların terekesinde bol miktarda yer aldığı görülmektedir.

Oğlu Kemal Bey’in yazdığı biyografiye göre hafızası oldukça kuvvetli olan Habib Efendi'nin Çağatayca ile diğer Türk lehçelerine merakı vardı. ${ }^{80}$ Kitaplığındaki Çağatay-ı Türkî Osmanî bu ilginin bir nişanesidir. Oğlunun aktardığına göre Muhyiddin Arabi, İbn Haldun, Ebülula, İbn Rüşd, Kemalüddini İsfehanî, Hakanî, Sadî, Hafız, Kaâni, Fuzuli, Nefî, Asım, Volter[Voltaire] ve Molyer [Molière]'i sever, Namık Kemal ve Şinasi'yi çok methederdi. ${ }^{81}$ Kitaplığın geneline bakıldığında Habib Efendi'nin sevdiği ve methettiği şahısların eserlerinin toplamından ibaret olduğu açıkça görülmektedir.

\section{Sonuç}

Mirza Habib İsfehanî, XIX. yüzyıl ortalarında bir kaçak olarak eriştiği Osmanlı başkentinde, sahip olduğu meziyetler ve entelektüel kişiliği sayesinde oldukça tanınan bir sima haline geldi. İstanbul'da Farsça ders kitapları yazarı, mütercim, muallim, müellif ve özellikle Ahter' in yazarlarından biri olarak tanınan Mirza’nın tüm bu faaliyetleri, Osmanlı devlet hizmetindeki yirmi beş yıllık memuriyet hayatı ile birlikte yürüdü. Mirza Habib İsfehanîye dair zengin sayılabilecek literatüre Mirza'nın terekesi bağlamında yazılan bu makale ile bir katkı sağlanmıştır. Zira, ömrünün yarısını Osmanlı topraklarında geçiren Mirza Habib'in ardında bıraktığı eşyaları ve kitaplarının bir listesini sunan bu tereke, ilk defa yayınlanmakta ve hem kendi biyografisine hem de dönem İstanbul'unda ait olduğu toplumsal tabakanın yaşam standartlarına dair önemli ayrıntılar sunmaktadır. Bu çalışma ile birlikte Habib Efendi'nin bilinen teknik biyografisine şahsi ilgi, tercih ve kullanımlarını ihsas ettiren daha öznel ve yeni bilgiler eklenmiştir. Ayrıca makalede ele alınan kitap listesinin, Mirza Habib'in kitaplığına/kütüphanesine dair bilgileri ilk defa gün yüzüne çıkararak entelektüel biyografisine katkı sağladığı şüphesizdir.

80 İnal, s. 474.

81 İnal, s. 474. 
Öz — İranlı entelektüel bir muhalif olarak hayatının yarısını Osmanlı başkentinde sürgünde geçiren Mirza Habib İsfehani'nin biyografisi, entelektüel ve siyasi kimliği hakkında oldukça zengin bir literatür vardır. Farsça ve Fransızca muallimliğinin yanı sıra müellifliği, mütercimliği sayesinde Dersaadet'in entelektüel muhitlerinde kısa sürede aranan isimlerden biri haline gelen Mirza Habib, Osmanlı bürokrasisindeki yirmi beş yıllık memuriyet tecrübesiyle birlikte Hat ve Hattatân ve Farsça ders kitapları yazarı, Sergüzeşt-i Hacı Baba-yı İsfehanînin mütercimi, İstanbul'un ilk ve en uzun soluklu Farsça gazetesi Ahter'in yazarlarından biri olarak haklı bir şöhrete sahip olur. Terekesine odaklanan bu makalenin amacı ise onun biyografisine ve entelektüel dünyasına ışık tutarak bir katkı sağlamaktır. Osmanlı Devleti'nin Farisî kökenli memuru Habib Efendi'nin şair ve entelektüel kişiliği ile mütenasip olarak ardında bıraktığı eşyaların büyük bir kısmını kitapları oluşturmaktadır. XIX. yüzyıl Fars edebiyatının önemli figürlerinden birinin ardında bıraktığı eşyaları ve özellikle kitaplarının listesi, Osmanlı/İran entelektüel hayatına dair pek çok ipucunu barındirmaktadır.

Anahtar kelimeler: Mirza Habib İsfehani, İstanbul, Acem, İranlı entelektüel, Fars dili ve edebiyatı, Kitap terekesi 


\section{EK 1}

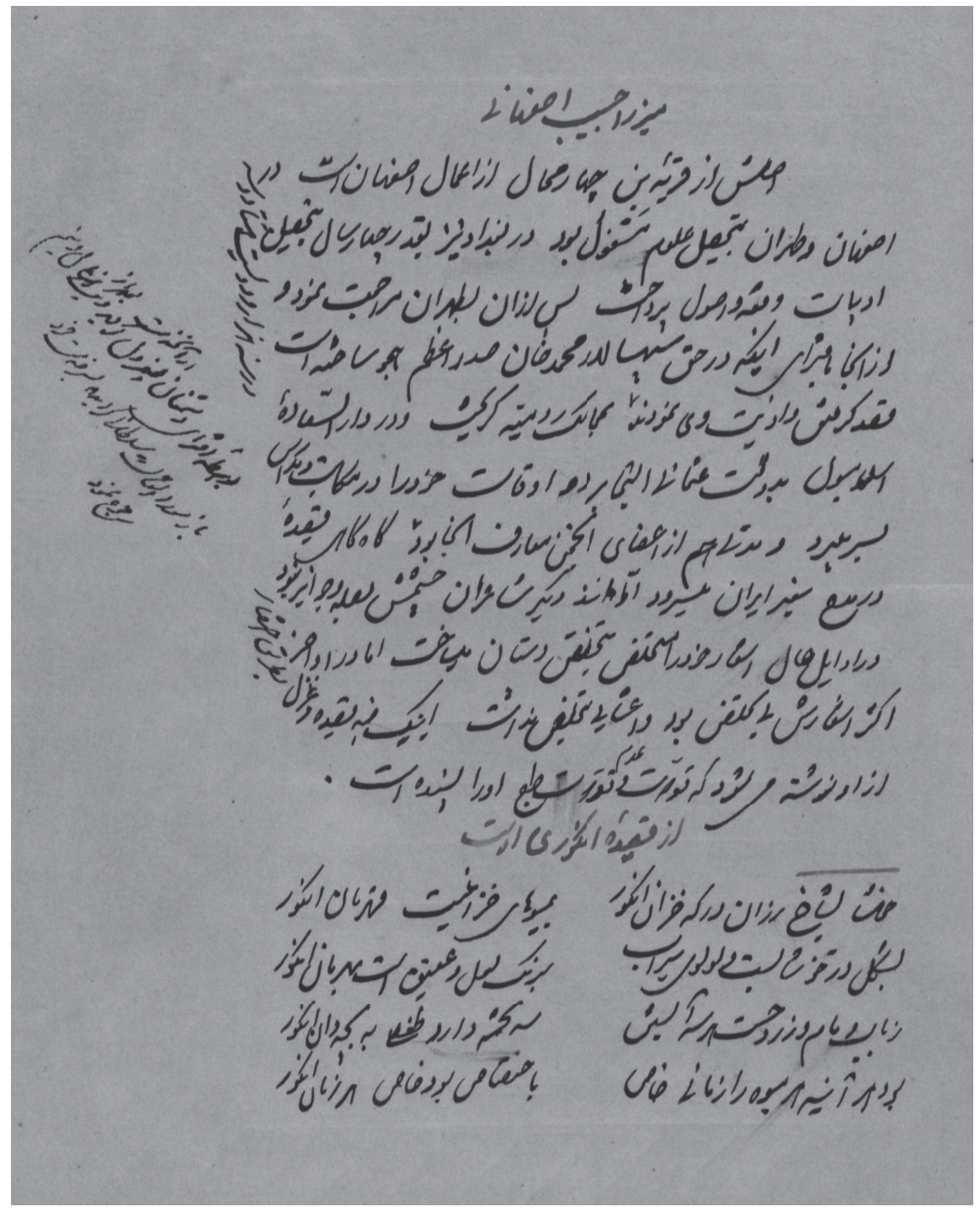

Mirza Habib İsfehani'nin kendi el yazısı ile yazdığı biyografisi (İstanbul Üniversitesi Nadir Eserler Kütüphanesi, F 712/42). 


\section{EK 2}

\section{HABİB EFENDİ TEREKE KAYDI ${ }^{82}$}

Mahrûse-i Galata'ya muzâfeten kasaba-i Tophane'de Defterdar Ebu'l-fazl mahallesinde sakin iken sene-i maliye 1309 senesi Mayısı'nın ibtidası günü vefat eden Maarif Nezaret-i celîlesi Encümen azasından Habib Efendi ibn Esedullah bin Abdullah'ın veraseti zevce-i menkûha-i metrûkesi İkbal Hanım ibnetü Abdullah ile zevce-i mumaileyhadan mütevellid ve sulb-i sağir mahdumları tahminen 14 yaşında Mehmed Cemal Bey ve tahminen 9 yaşında Ahmed Celal Bey ve kendüden mukaddem vefat eden zevcesi Fatümatü'z-zehra Hanım ibnetü Hasan bin Abdullah'dan mütevellid sulb-i kebiri mahdumu Mehmed Kemal Bey'e munhasıra[münhasıran] olduğu ve bi'l-ihbar ve lede'ş-şer 'i'l-enver zahir ve mütehakkık olduktan sonra sağirâna mumaileyhanın valideleri ve tesviye-i imrarına ba-hüccet-i şeriyye vasi-i mensubeleri zati mu'arrefe zevce-i mumaileyha İkbal Hanım bi'l-asâle ve bi'l-vesâye ve mumaileyh Mehmed Kemal Bey tarafından vekil müseccel-i şerisi Ahmed Muhtar Bey ibn Abdullah bi'l-vekale talep ve marifetleri ve marifet-i şer'le tahrir-i deyn ve sim-i mecidiyyeye 20 kuruş hesabıyla bi'l-müzayede ahere bey' ve beyne’l-verese tevzî‘ ve taksîm olunan tereke müteveffa-yı mumaileyhdir ber-vech-i ati zikr olunur fî 17 Zilhicce 310

Müteveffa-yı mumaileyhin Kredi Liyon Bankası'na ba-sened matlûbu olup ba-tezkire banka-i mezkûreden kabz olunan

54138 lira-yı Osmanî

38 Bank-1 mezkûrdan meblağ-1 mezkûrun deyn tahsilinde verilen

54100 pul bahası ve masarif

1464 Resm-i kısmet kaydiyye ve pul-1 müteferrika

52636 Sahhüll-baki li't-taksim

82 Kısmet-i Askeriye Mahkemesi, 1940 numaralı defter, s. 73-75. 
Hisse-i el-zevcetü'l mezbûre İkbal Hanım 6579,5 kuruş

Hisse-i el-ibnü's-sağir el-mezbûr Mehmed Cemal Bey 15352 kuruş 20 akçe Hisse-i el-ibnü's-sağir el-mezbûr Ahmed Celal Bey 15352 kuruş 20 akçe

Hisse-i el-ibnü’l-mezbûr Mehmed Kemal Bey 15352 kuruş 20 akçe

Zevce-i mumaileyha İkbal Hanım bâlâda muharrer hisse-i veresiyyesi olan altı bin beş yüz yetmiş dokuz buçuk kuruşu tereke-i müteveffa-yı mumaileyhden tamamen ve kâmilen ahz u kabz ve istifa-yı hakk ettikten sonra vekil-i mumaileyh Ahmed Muhtar Bey müvekkili mumaileyh Mehmed Kemal Bey'in kezalik bâlâda muharrer hisse-i ırsiyyesi olan on beş bin üçyüz elli iki kuruş yirmi akçeyi kezalik tereke-i müteveffa-yı mumaileyhden bil-vekale ahz u kabz ve istifa-yı hakk ettikten sonra sağirân-1 mezbûrânın kezalik bâlâda muharrer hisse-i ırsiyyeleri olan cem'an otuz bin yedi yüz dört kuruş kırk akçenin sekiz yüz kuruşunu bi'l-izni’şşer'i hatab ve kömür bahasıçün vasi-i mumaileyh İkbal Hanım bi'l-vesaye ahz u kabz etmekle lede't-tenzil mâadâsı olan yirmi dokuz bin dokuz yüz dört kuruş kırk akçe vasi-i mumaileyh marifeti ve marifet-i şer'le bir tahta sandığa mevzû́an ve memhûren li-ecli'l-hıfz Bezzazistân-1 atîk'a emaneten irsâl olunduğu ve işbu mahalle şerh olundu

Ba'de'd-defter müteveffâ-yı mumaileyhin zikr-i âti terekesi zuhûr etmekle verese-i münhasırasından sernâme-i defterde isimleri mezkûr sağirân-1 mezbûrânın valideleri ve vasi-i mensûbeleri zevce-i mumaileyha İkbal Hanım tarafından hususu âtîde vekil-i müseccel-i şer 'isi nezaret-i müşarunileyha müfettişlerinden faziletlü el-Hâc Hafız Hüseyin Hüsnü Efendi ibn İbrahim ve vekil-i mumaileyh Ahmed Muhtar Bey'den her birinin bi'l-vekâle taleb ve marifetleri ve marifet-i şer'le tahrir ve beher sim mecidiye yirmi kuruş hesabıyla bil'l-müzayede âhere bey' ve beyne'l-verese tevzî‘ ve taksîm ve zeyl-i defter olunduğu ber-vech-i âti zikr olunur fî 21 Safer 311

Müteveffa-yı mumaileyhin mahalle-i mezbûrede vâki' ile'l-vefat sakin olduğu menzil-i derûnunda âhere bey' olunan eşyasıdır ki zikr olunur 


\begin{tabular}{|c|c|c|}
\hline Adet & Eşya & Fiyat/kuruş \\
\hline 1 & Tepegöz altın saat & 800 \\
\hline 1 & Çalar altın koyun saati & 451 \\
\hline 1 & Sim saat & 99 \\
\hline 1 & Sağir sim kupa ma` sim hırdavat & 46 \\
\hline 2 & Kırmızı pantalon & \multirow{3}{*}{50} \\
\hline 2 & Setri & \\
\hline 1 & Kuşak & \\
\hline 2 & Defa kırmızı pantalon & \multirow{3}{*}{90} \\
\hline 2 & Yelek & \\
\hline 1 & Palto & \\
\hline 2 & Pantalon & \multirow{3}{*}{47} \\
\hline 2 & Yelek & \\
\hline 1 & Bohça & \\
\hline 1 & Kastor palto & \multirow{3}{*}{$371 ?$} \\
\hline 1 & Kırmızı palto & \\
\hline 1 & Yelek & \\
\hline 2 & Çuka yelek & \multirow{3}{*}{152} \\
\hline 1 & Pantolon & \\
\hline 1 & Pardesü & \\
\hline 1 & Çuka setri & \multirow{2}{*}{15} \\
\hline 2 & Yelek & \\
\hline 1 & Çuka redingot & 152 \\
\hline 1 & Kastor kaput & 160 \\
\hline 1 & Sakoya kaplı samur kürk & 249 \\
\hline 4 & İrankârî basma pencere ve perde & 72 \\
\hline 8 & Basma pencere perde & \multirow{2}{*}{54} \\
\hline 1 & Yelek? & \\
\hline 1 & Dağırcık ma' hırdavat & 32 \\
\hline 2 & Köhne sebet sandık & 31 \\
\hline 1 & Çukaya kaplı köhne cild kafa kürk & \multirow{2}{*}{130} \\
\hline 1 & İrankâri maslah & \\
\hline 3 & İrankâri çorap çift ma' hırdavat & 32 \\
\hline
\end{tabular}




\begin{tabular}{|c|c|c|}
\hline 11 & Don & \multirow{5}{*}{31} \\
\hline 2 & Fanila gömlek & \\
\hline 1 & Hırka & \\
\hline 2 & Entari & \\
\hline 1 & Boğça & \\
\hline 10 & Elvan havlu ma' hirdavat & 40 \\
\hline 3 & Çarşab ma bez hırdavatı & 61 \\
\hline 1 & Battaniye & 26 \\
\hline 1 çift & Terlik & 32 \\
\hline 6 & Beyaz gömlek & 20 \\
\hline 1 & İrankâri pencere perde & 15 \\
\hline 3 & Elvan hırka & \multirow{2}{*}{33} \\
\hline 1 & Başlık & \\
\hline 1 & Trabzonkâri parça bez & 80 \\
\hline 1 & Çorap çift & \multirow{2}{*}{19} \\
\hline 3 & Yelpaze ma' hırdavat & \\
\hline 4 & Frenkkârî gömlek & 16 \\
\hline 2 & Ot memlu minder & \multirow{12}{*}{300} \\
\hline 1 & Şilte & \\
\hline 1 & İhram makad & \\
\hline 7 & Yastık & \\
\hline 2 & Yüz yastığı & \\
\hline 5 & Perde & \\
\hline 7 & Gaz lamba & \\
\hline 3 & Sürahi & \\
\hline 2 & Bardak & \\
\hline 2 & Saks1 & \\
\hline 3 & Sandalye & \\
\hline 1 & Mirat & \\
\hline 5 & Elvan yorgan ma' çarşab & 150 \\
\hline 1 & Güğez battaniye & \\
\hline 1 & Post & \\
\hline 1 & Tüylü gâşiye & 60 \\
\hline
\end{tabular}




\begin{tabular}{|c|c|c|}
\hline 3 & Penbe şilte & \multirow{2}{*}{169} \\
\hline 1 & Yatak bağı & \\
\hline 3 & İrankârî yorgan ma' çarşab & \multirow{2}{*}{200} \\
\hline 1 & Azarak & \\
\hline 1 & Harar & 20 \\
\hline 1 & Şilte & \\
\hline 1 & Hasır & \\
\hline 1 & Yastık & 30 \\
\hline 1 & Asa & \\
\hline 1 & Balta & 30 \\
\hline 1 & Devat & \\
\hline 2 & Hokka & \\
\hline 1 & Ruhdan & 39 \\
\hline 1 & Rovalver ma' takım & 131 \\
\hline 1 & Defa rovalver & 121 \\
\hline 9 & İrankârî sahan & \\
\hline 2 & Tepsi & 39 \\
\hline 1 & Nühas lenger ma' çanak & 20 \\
\hline 5 & Kupa & \multirow{5}{*}{1} \\
\hline 7 & Tabak & \\
\hline 2 & Tepsi & \\
\hline 5 & Zarf & \\
\hline 1 & Şamdan & \\
\hline 2 & Yemişlik & \multirow{3}{*}{15} \\
\hline 1 & Sürahi & \\
\hline 5 & Tabak & \\
\hline 1 & Ceb rovalveri & 40 \\
\hline 1 & Biçak & 5 \\
\hline 10 & Maden kaşık & \multirow{4}{*}{81} \\
\hline 8 & Çatal & \\
\hline 10 & Bıçak & \\
\hline 10 & Kaşık ma' hırdavat & \\
\hline
\end{tabular}




\begin{tabular}{|c|l|r|}
\hline 1 & Tahta dolap & 52 \\
\hline 1 adet & Camlı dolap & 100 \\
\hline 1 & Şark köy kilim & 470 \\
\hline 1 & Defa Şark köy kilim & 179 \\
\hline 1 & Kırşehir seccade & 56 \\
\hline 1 & Kitap rafı & 36 \\
\hline 1 & Şatranç tahta ma takım & 110 \\
\hline 1 & İrankârî kilim & 57 \\
\hline 1 & Tüy şilte & 10 \\
\hline 2 & Yastık & \\
\hline 1 & Duvar rafı & 86 \\
\hline 1 & Yün memlu döşek & 162 \\
\hline 2 & Yastık & \\
\hline 1 & Şilte & \\
\hline 1 & Ot memlu minder & \\
\hline 2 & Yastık & \\
\hline 1 & Camlı kütüphane & \\
\hline 2 & Ot memlu minder & \\
\hline 6 & Yastık & \\
\hline 1 & Makad & \\
\hline 4 & pencere perde & \\
\hline 2 & Ot memlu minder & \\
\hline 4 & Yastık & \\
\hline 2 & Perde & \\
\hline 1 & Camlı dolap & \\
\hline 1 & Sarı Mangal & \\
\hline 1 & Kazgan & \\
\hline 2 & Sini & \\
\hline 1 & Cameşuy leğeni & \\
\hline 7 & Tencere & \\
\hline 1 & Yumurta tabe & \\
\hline 1 & Yağ tabe & \\
\hline 5 & Sahan & \\
\hline 1 & Çorba Tabesi & \\
\hline 1 & Pilav tabe ma` matbah hırdavatı & \\
\hline & & \\
\hline
\end{tabular}




\begin{tabular}{|c|l|r|}
\hline 2 & Ot memlu minder & \\
\hline 8 & Yastık & \\
\hline 3 & Erkan & \\
\hline 6 & Yüz Yastığı & \\
\hline 1 & Yazıhane & \\
\hline 1 & Mirat & 32 \\
\hline 1 & Duvar rafı & 28 \\
\hline 1 & Yorgan & 40 \\
\hline 1 & Kapı perde & 72 \\
\hline 1 & Tahta sandalye & 10 \\
\hline 6 & Hezârâne sandalye & 18 \\
\hline 2 & Bıçak & 45 \\
\hline 1 & Çakı & 7285 kuruş $^{82}$ \\
\hline 1 & Abanoz çekmece & \\
\hline & YEKÜN & \\
\hline
\end{tabular}

Müteveffa-yı mumaileyhin Çarşı-yı kebir'de Bezzazistân-ı atik ve Sahaflar Çarşısı'na nakille âhere bey' olunan eşya ve kütüb-i mütenevviasıdır ki ber-vech-i âti zikr olunur

\begin{tabular}{|c|l|r|}
\hline Adet & Kitap/Eşya & Kuruş \\
\hline 1 & Altın saat ma' kordonu & 874 \\
\hline 1 & Köhne çuka palto & 88 \\
\hline 1 & Yakutî hattıyla kebir yazma Kelam-1 kadim & 995 \\
\hline 7 & Yazı levha & 68 \\
\hline 1 & Divan-1 Hekim Sûzenî & 300 \\
\hline 1 & Mukaddime-i Hacı Baba & 1500 \\
\hline 1 & Divan-1 Emir Hüsrev Dehlevi/Dihlevi ba-hat & 3300 \\
\hline 1 & Talik murakka kıta & 250 \\
\hline 1 & Yazma Hamse-i Enzamî [Nizami] & \\
\hline 1 & Divan-1 Attar & \multicolumn{1}{|c|}{} \\
\hline
\end{tabular}

82 Yaptığımız hesaplamada toplam 7214 kuruş olarak çıkmıştır. Katip hesaplaması ile aradaki 71 kuruşluk fark, yanlış hesaplamadan ya da terekedeki meşkuk bazı rakamların tarafımızdan yanlış okunmasından kaynaklanmış olabilir. 


\begin{tabular}{|c|c|c|}
\hline 1 & Hafız Divanı & \multirow{4}{*}{280} \\
\hline 1 & Menâzir-i İnşâ & \\
\hline 1 & Hace Kirmanî & \\
\hline 1 & Gülistan ve Bostan & \\
\hline 1 & Divan-1 Mecdüddin & \multirow{3}{*}{130} \\
\hline 1 & Şerefnâme & \\
\hline 1 & Menâkıb-1 Hünerverân & \\
\hline 1 & Tezkiretü’şsşuarâ & \multirow{4}{*}{460} \\
\hline 1 & Elfiyye fi's-siyer li'l-Halebî & \\
\hline 1 & Divan-1 Abdü’l-vasi` Çelebi & \\
\hline 1 & Divan-1 Emir Muizzi & \\
\hline 1 kıta & Divan-1 Kemal İsfehanî & 240 \\
\hline 1 kıta & Hace Kirmanî & \multirow{2}{*}{160} \\
\hline 1 & Penc Hacu Kirmanî & \\
\hline 1 & Divan-1 Mecd-i Hemger & \multirow{2}{*}{300} \\
\hline 1 & Mecmua-i Eşâr-i Fâris & \\
\hline 2 & (yazma) Gülistan & 200 \\
\hline 1 kıta & Ebyât-1 Şeyh Irâkî & \multirow{3}{*}{24} \\
\hline 1 & Divan-1 Vassaf Merzubânnâme & \\
\hline- & Divan-1 Mazhar Cemaleddin İsfehanî & \\
\hline 1 & Zeyl-i Takvim & 45 \\
\hline 1 & Divan-1 Necâtî & 160 \\
\hline 1 & Divan-1 Nur Ali & \multirow{2}{*}{22} \\
\hline 1 & Raşid & \\
\hline 1 & Hadâikü’s-sihr & \multirow{3}{*}{62} \\
\hline 1 & Aruz-1 Farisî & \\
\hline 1 & Mecmua-i Aruz & \\
\hline 2 kıta & Murakka & 43 \\
\hline 1 & Kudûrî & \multirow{6}{*}{3} \\
\hline 1 & Evzahül-Mesâlik & \\
\hline 1 & Vasiyet-i İmam-1 Azam & \\
\hline 1 & Farisî Sarf Mecmua & \\
\hline 1 & İzhar & \\
\hline 1 & Fikh-1 Şafi & \\
\hline
\end{tabular}




\begin{tabular}{|c|c|c|}
\hline 1 & Kitabü'l-Vâfî Assâr & 40 \\
\hline 1 & Lugat-1 Mühezzeb & \multirow{2}{*}{21} \\
\hline 1 & Dekâyıku’l-Hakâyık & \\
\hline 1 & Kâsımül'-envâr & 200 \\
\hline 1 & Mantıku't-Tayr & 80 \\
\hline 1 & Mesnevi-i şerif & 330 \\
\hline 1 & Bostan & \multirow{2}{*}{60} \\
\hline 1 & Hafiz & \\
\hline 1 & Miratü'l-Cemal & \multirow{2}{*}{35} \\
\hline 1 & Bahrü’l-Maarif & \\
\hline 1 & (Yazma) Tûtînâme & 39 \\
\hline 1 & Mukaddimetü'l-Edeb & \multirow{3}{*}{220} \\
\hline 1 & Gülistan & \\
\hline 1 & Lugat-i Hekîmî & \\
\hline 1 & Müntehâb-1 Mesnevi & \multirow{2}{*}{59} \\
\hline 1 & Subhatü’l-Ebrâr & \\
\hline 1 & Tezkire-i Devlet Şah & 57 \\
\hline 1 & Telhis & \multirow{2}{*}{60} \\
\hline 1 & Çihil Hadis & \\
\hline 1 & Kenz & \multirow{3}{*}{4} \\
\hline 1 & Enam-1 şerif & \\
\hline 1 & Hülasa-i Hamsiyye & \\
\hline 1 & Mantık Fârisî & \multirow{3}{*}{13} \\
\hline 1 & Lugat-1 Fârisî & \\
\hline 1 & Durûb-1 Emsâl & \\
\hline 1 & (yazma) Cevâmiü’l-lezze Kâşânî & 319 \\
\hline 1 & Ubeyd Zâkânî & 145 \\
\hline 1 & Esâmi fi'l-esâmi & 45 \\
\hline 1 & İmadüddin Kirmanî & 134 \\
\hline 1 & Gülistan-1 Sadi & 210 \\
\hline 1 & Külliyat-1 Cami & 300 \\
\hline- & (bâ-hat [yazma]) Davut ibn Müteaddide & 102 \\
\hline 1 & Tercüman-1 Lugat & 14 \\
\hline- & Tefsir-i Hüseyin Vaiz & 460 \\
\hline
\end{tabular}




\begin{tabular}{|c|c|c|}
\hline 1 cild & Hülasatü't-Tevârih & 40 \\
\hline 1 cild & Hülasa-i Divan & 45 \\
\hline 1 & Divan-1 Cami & 95 \\
\hline 1 & Bostan & \multirow{3}{*}{200} \\
\hline 1 & Hafiz & \\
\hline 1 & Kitaat-1 ibn-i Yemin & \\
\hline 1 cild & Mecâlisü'n-nefâis & 285 \\
\hline 1 & Muizzi Çelebi & \multirow{3}{*}{59} \\
\hline 1 & Tarih-i Timur & \\
\hline 1 & Hüsn-i Aşk & \\
\hline 1 & (Sağir kıta) Mushaf-ı serif & 395 \\
\hline 1 & Ebyât-1 Hümâyûnnâme & \multirow{3}{*}{40} \\
\hline 1 & Mültemisât & \\
\hline 1 & Tasavvuf & \\
\hline 1 & Mesnevi-i şerif tercüme & \multirow{5}{*}{3} \\
\hline 1 & Tercümeli Hafız & \\
\hline 1 & Hülasatü’l-Hisâb & \\
\hline 1 & Münâzarâtü hams & \\
\hline 1 & Tarih-i Mu'cem & \\
\hline 2 & Sağir Aruz & \multirow{2}{*}{10} \\
\hline 2 & Kelimât-1 Hazret-i Ali & \\
\hline 1 & Lugat-1 Nevâdirât & \multirow{2}{*}{70} \\
\hline 1 & İrade-i cüz iyye & \\
\hline 1 & Cönk & 61 \\
\hline 1 & Mecmua-i Nefise & 1000 \\
\hline 1 & Divan-1 Hafız Hacu Kirmanî & 55 \\
\hline 1 & Divan-1 Hafız bâ- hatt-1 talik kıta ma' mahfaza & 210 \\
\hline 1 & Divan-1 Hakanî & 160 \\
\hline 1 & Külliyât-1 Cami & \multirow{2}{*}{100} \\
\hline 1 & Hafiz & \\
\hline 1 & Divan-1 Vasfi & \multirow{2}{*}{30} \\
\hline 1 & Eşâr-1 Arabiyye & \\
\hline 1 & İlahi Mecmua & 35 \\
\hline
\end{tabular}




\begin{tabular}{|c|c|c|}
\hline 1 & Divan-1 Şâhî & \multirow{3}{*}{400} \\
\hline 1 & Ferruh & \\
\hline 1 & Risale-i hat & \\
\hline 1 & Kelimât-1 Hazret-i Ali & \multirow{2}{*}{81} \\
\hline 1 & Örfî & \\
\hline 1 & (Yazma) Nadirşah Tarihi & 49 \\
\hline 1 cild & (Yazma) Divan-1 Sầib & 58 \\
\hline 1 cild & (Yazma) Keşfü̉l-Ervâh & 188 \\
\hline 1 & (Yazma) Evhadî Divanı & 260 \\
\hline 1 cild & Uklûmü'l-luga & 16 \\
\hline 1 & (Yazma) Aruz ma' Divan-1 Seyfi & 34 \\
\hline 1 & Şerh-i Merah Câğmûnî & 35 \\
\hline 1 & Mecmua-i Gazaliyat & 215 \\
\hline 1 & Misbâh & \multirow{2}{*}{41} \\
\hline 1 & Câmiü’l-Kavâid & \\
\hline 1 cild & Yusuf Züleyha & 22 \\
\hline 1 & Cami İnşa & \multirow{2}{*}{37} \\
\hline 1 & Hadikatü’s-sihr & \\
\hline 1 & (Yazma) Gülistan & \multirow{2}{*}{82} \\
\hline 1 & Habnâme-i Yusufî & \\
\hline 1 & (Yazma) Tayyib-i Yusufi & \multirow{2}{*}{49} \\
\hline 1 & Divan-1 Kelîm & \\
\hline 1 & Kenzü’l-Hakâyık & \multirow{3}{*}{40} \\
\hline 1 & Düstûru'l-amel & \\
\hline 1 & Lugat-1 Fârisî & \\
\hline 1 & İlm-i Nücûm & \multirow{3}{*}{40} \\
\hline 1 & Netâyic-i Fünûn & \\
\hline 4 & Delâil-i Hayrât & \\
\hline 1 & Edhem Divanı & \multirow{3}{*}{38} \\
\hline 1 & Nuri & \\
\hline 1 & Nisâb-1 Pend-i Attar & \\
\hline 1 & Tarih-i Mahmud & \multirow{3}{*}{23} \\
\hline 1 & Takvim-i Çelebi & \\
\hline 1 & Divan-1 Fuzuli & \\
\hline
\end{tabular}




\begin{tabular}{|c|c|c|}
\hline 1 & Enzârü'l-efkâr & \multirow{4}{*}{4} \\
\hline 1 & Sa'lebî & \\
\hline 1 & Ta'rifât-1 Seyyidî & \\
\hline 1 & Telhis & \\
\hline 1 & Mağribî & \multirow{3}{*}{34} \\
\hline 1 & Hulasatül'-ahbâr & \\
\hline 1 & Bostan tercüme & \\
\hline 1 & Kelimât-1 Hikemiyye & \multirow{3}{*}{51} \\
\hline 1 & Edebiyat & \\
\hline 1 & Envârül-Emsâl & \\
\hline 1 & Esasü’l-iktibas & \multirow{3}{*}{45} \\
\hline 1 & Rubaiyyat & \\
\hline 1 & Mevlana Mecmau'l-Emsâl & \\
\hline 1 & Divan-1 Ferah & \multirow{2}{*}{22} \\
\hline 1 & Ravzatü'l-Uşşak & \\
\hline 1 & Kitab-1 Hesab & \multirow{4}{*}{79} \\
\hline 1 & Müntehebât & \\
\hline 1 & Mirkatü’l-Edeb & \\
\hline 1 & Mihr [ü] Müşteri & \\
\hline 1 & Münşe'ât-1 Türkiyye & \multirow{3}{*}{20} \\
\hline 1 & el-Tầif [Letâif] & \\
\hline 1 & İskender-i Rumî & \\
\hline 1 & Kasẩid-i Erbaîn & \multirow{4}{*}{61} \\
\hline 1 & Yusuf Celal & \\
\hline 1 & Irakî Divanı & \\
\hline 1 & Dehnâme-i ibn İmad & \\
\hline 1 & Nahv-1 Harunî & \multirow{2}{*}{12} \\
\hline- & Şerh-i Kuran-1 Kerim'den bir cüz & \\
\hline 1 & Leyla ve Mecnun Divanı & \multirow{3}{*}{20} \\
\hline 1 & Hafikî & \\
\hline 1 & Şirin ve Ferhad Vahşi & \\
\hline 5 alayı & İbn-i Sina Ali & 18 \\
\hline 2 & Ragıp Paşa Divanı ve Mecmua & 31 \\
\hline
\end{tabular}




\begin{tabular}{|c|c|c|}
\hline 1 & Hadâikü'l-Hakâyık & \multirow{2}{*}{13} \\
\hline 1 & Lugat & \\
\hline 4 alayı & Tuhfetü'l-ahbâb & 23 \\
\hline 9 alayı & Mecmua & 66 \\
\hline 1 & Gülşen-i Râz & 88 \\
\hline 1 & Mecmua & 100 \\
\hline 1 & Hadis-i Erbâin & \multirow{2}{*}{21} \\
\hline 1 & İnşa-i İmâdi & \\
\hline 1 & Sâika & 41 \\
\hline 1 & Tuhfetül-Vüzerâ & \multirow{3}{*}{7} \\
\hline 1 & Mecmua-i muhtelife-i Eşsârî & \\
\hline- & Vasiyet-i Emirü’l-müminîn-i Hazret-i Ali & \\
\hline 1 cild & Münâcât-1 Abdullah Ensarî & \multirow{2}{*}{22} \\
\hline 1 & Eşấ[r]-1 Ali & \\
\hline $\begin{array}{c}15 \\
\text { alay1 }\end{array}$ & Evrak-1 Perişan & 16 \\
\hline 1 & Sabit Divanı & 21 \\
\hline 1 cild & (Basma) Keşfü̉z-zünûn & 225 \\
\hline 1 & (Basma) Hümâyûnnâme & 19 \\
\hline 2 cild & Mecmau’l-Fusahâ & 199 \\
\hline 1 & Arapça Kâmûs & 47 \\
\hline 2 cild & Lehçetül-luga & 17 \\
\hline 2 cild & Tâcü’t-târih & 29 \\
\hline 1 & Lehçe-i Osmanî & 13 \\
\hline 1 & Nisâb-1 Sıbyân aruzdan & \multirow{3}{*}{2} \\
\hline 1 & Nevâdir-i Süheylî & \\
\hline 2 & Lehçe-i Osmanî & \\
\hline 31 cild & Kavânîn-i âl-i Osman- 16 pare & 12 \\
\hline 1 & Külliyat-1 Kelîle-i Dümniyye [Dimne] & 20 \\
\hline 2 & Lehçe-i Osmanî & 14 \\
\hline 42 & Bostan- 29 pare & $\begin{array}{r}30,18 \\
\text { para } \\
\end{array}$ \\
\hline 32 & Debistân-1 Fârisî- 42 pare & 33,5 \\
\hline 32 & Mizan Tercemesi Turub [Mizantrope] & 5 \\
\hline
\end{tabular}




\begin{tabular}{|c|c|c|}
\hline 72 & Berg-i sebz & 4,5 \\
\hline 20 & Münâcât-1 Abdullah Ensarî & 5 \\
\hline 34 & Mümâresât-1 Fârisiyye & 6 \\
\hline 20 & Ubeyd-i Zakanî & 25 \\
\hline 7 & Mahbûbül-Kulûb & 9 \\
\hline 5 & Tarih-i Osmaniyye & 7,5 \\
\hline 1 cild & Ferah Ba'deş-şidde & 21 \\
\hline 1 & Komedya ma' hirdavat & 16 \\
\hline 2 cild & (Basma) Muhâdarât-1 Ragıb & 48 \\
\hline 1 & İbn-i Haldun Mukaddime & 32 \\
\hline 1 cild & (Yazma) Divan-1 Ebî Nevâsil/Nüvvas[?] & 258 \\
\hline 1 & (Yazma) Ferheng-i Cihangir & 82 \\
\hline 1 & (Yazma) Kimya-yı Saadet & 20 \\
\hline 1 & (Yazma) Mirkâtü’l-Luga & 40 \\
\hline 1 & Risâle-i Nefise der İlm-i Musiki & 152 \\
\hline 1 & (Yazma) Divan-1 Enverî & 130 \\
\hline 1 & Cönk-i Kuçek & 50 \\
\hline 1 cild & (Basma)Mecmua-i Arabiyye Resâil-i Ebubekir el-Hârezmî & 56 \\
\hline 1 & (Yazma) Lugatü'l-Lehce & 36 \\
\hline 6 alayı & Külliyât-1 Saadettin & 40 \\
\hline 1 & (Basma) Malumâtü’l-Afâk & \multirow{3}{*}{6} \\
\hline 1 & Bostan & \\
\hline 1 & Kadâhet (?) & \\
\hline 1 & Divan-1 Nazirî & \multirow{2}{*}{43} \\
\hline 1 & Hafız Divanı & \\
\hline 3 alayı & Fikhu'l-luga & 37 \\
\hline 4 alayı & Dürretü'l-yetime & 10 \\
\hline 1 & (Basma) Ziynetü’l-mecâlis & 21 \\
\hline 4 & Franseviyyü'l-ibare kütüb & 25 \\
\hline 5 alayı & Milel Nihal & 29 \\
\hline 4 alay1 & Kınizüs'sshha & 20 \\
\hline 1 & Müfredâtü’t-Tib & 19 \\
\hline 6 alayı & Mahbûbüll-Kulûb & 12 \\
\hline 5 alayı & Nesimü’s-saba & 20 \\
\hline
\end{tabular}




\begin{tabular}{|c|c|c|}
\hline 1 & (Yazma) Mecmua & 66 \\
\hline 7 alay 1 & Kenzü’l-Esrâr & 22 \\
\hline 1 & Elfü'l-Leyle & 41 \\
\hline 4 alay & Müntehabât-1 Mesnevî & 24 \\
\hline 1 & Külliyât-1 Attar & 101 \\
\hline 1 & Müfredât-1 Kuran & \multirow{2}{*}{138} \\
\hline 1 & Şifa-i şerif & \\
\hline 1 & (Basma) Genc-i Şâkiyân & 28 \\
\hline 3 alayı & Gurerü’l-Kavâid & 30 \\
\hline 3 & İbn-i Hallikân & 98 \\
\hline 1 & Bostan Rubaiyat Külliyat-1 Sadi & 29 \\
\hline 1 & Kuşeyriyye Risalesi & \multirow{3}{*}{27} \\
\hline 1 & Seb'iyyât & \\
\hline 1 & Külliyât-1 Nevâi & \\
\hline 4 alayı & Ünvanüll-beyan & 28 \\
\hline 3 alayı & Seyâhatnâme & 60 \\
\hline 1 & Kurretü'l-uyûn ve'n-nüfus & \multirow{2}{*}{10} \\
\hline 1 & Kitabü'l-benât & \\
\hline 4 alayı & Sülûkü'l-mesâlik & 17 \\
\hline 1 & Ziyâül-gayrîn & 10 \\
\hline 3 alayı & Muallakat-1 Seyyid & 25 \\
\hline 1 & Divan-1 Hüsrev & 11 \\
\hline 5 alayı & Divan-1 Hamidî & 45 \\
\hline 1 & Endülüs Tarihi & 21 \\
\hline 5 alay1 & Ravzatül-ahbâr & 8 \\
\hline 4 alay1 & Islah-1[Istılah-1] Sufiyye & 36 \\
\hline 1 & Ahlak-1 Muhsinî & 4 \\
\hline 5 alayı & Tarih-i Kirmanî & 12 \\
\hline 1 & Ahlak-1 Nâsırî & \multirow{2}{*}{31} \\
\hline 1 & (Yazma) Mecmua-i Tarih & \\
\hline 1 & Murakka bâ-hatt-1 talîk & 31 \\
\hline 5 alayı & Coğrafya & 10 \\
\hline 4 alayı & Menârü'l-izhâr & 15 \\
\hline 5 alayı & Mantık & 7 \\
\hline
\end{tabular}




\begin{tabular}{|c|c|c|}
\hline 2 & (Yazma) Talîk risale & 130 \\
\hline 2 & (Yazma) Dua risale & 50 \\
\hline 3 & Kitap kabları & 255,5 \\
\hline 1 & (Basma) Füsûl-i Bedâyi` & 15 \\
\hline 1 & (Basma) Şâhnâme Firdevsînin & 84 \\
\hline 1 & Hatt-1[Hat ve] Hattatân & 21 \\
\hline 1 & Ahlak-1 Alâ̂ & \multirow{3}{*}{17} \\
\hline 1 & Tarih-i Emsal & \\
\hline 1 & Muhtar-1 Sıhâh & \\
\hline 1 & Kalâatî ? & 37 \\
\hline 4 cild & Ulûm-1 riyâziyye & 18 \\
\hline 1 alay 1 & Tarih-i İskender & \multirow{3}{*}{3} \\
\hline 1 & Tuhfe-i İlahiyye & \\
\hline 1 & Ebi'l-fazl Bedâyi'ü’z-zaman & \\
\hline 1 & Mecma ü’l-Bahreyn & 63 \\
\hline 1 & Fuzuli Divanı & \multirow{4}{*}{33} \\
\hline 1 & Misbâhü’t-tâlibîn & \\
\hline 1 & İmruü'l-Kays & \\
\hline 1 & Kelile & \\
\hline 2 cild & Muhitül-muhit & 72 \\
\hline 1 & Keşkül-i Bahaî & \multirow{2}{*}{22} \\
\hline 1 & Tezyinü’l-Esvâk Lugat-1 Osmanî & \\
\hline 1 & Tarih-i Nadir & 39 \\
\hline 1 cild & (Basma) Hadikatü'l-hakika & 34 \\
\hline 1 & Divan-1 Hamâse & \multirow{4}{*}{26} \\
\hline 1 & İmruü'l-Kays & \\
\hline 1 & Gülşen-i Râz & \\
\hline 1 & Divan-1 Hafâce & \\
\hline 1 & Envâr-1 Süheylî & 23 \\
\hline 1 & Tûtînâme & \multirow{4}{*}{15} \\
\hline 1 & Kâmil-i Kelâm & \\
\hline 1 & Seyahatnâme & \\
\hline 1 & Musavver Türkistan & \\
\hline
\end{tabular}




\begin{tabular}{|c|c|c|}
\hline 1 & Divan-1 Et'ime & \multirow{2}{*}{20} \\
\hline 1 & Tuhfe-i İlahiyye & \\
\hline 1 & Âteşgede & 25 \\
\hline 3 alay 1 & Tertib-i Zîbâ & 18 \\
\hline 3 alayı & Hafız Divanı & 19 \\
\hline 1 alayı & Divan-1 Muhyi- 3 & 23 \\
\hline 5 alayı & Tarifât-1 Seyyidî & 12 \\
\hline 3 alayı & Divan-1 Hafız & 22 \\
\hline 1 & Elf el-leyle ve'l-leyle & 19 \\
\hline 1 & Zehrü'r-rabi‘ & \multirow{2}{*}{30} \\
\hline 1 & Ferah ba'de'ş-şidde & \\
\hline 5 alayı & Fuzuli'nin Hadikatü’s-Süeda & 13 \\
\hline 6 alay 1 & Nukûd-1 kadime & 16 \\
\hline 1 & Keşkül-i Bahai & \multirow{2}{*}{10} \\
\hline 1 & Aruz- 5 ma' alay 1 & \\
\hline 5 alayı & Tuhfetül-aruz & 19 \\
\hline 3 alayı & İbn-i Haldun & 30 \\
\hline 3 alayı & Tuhfetül-âlem & 16 \\
\hline 8 alayı & Mecmua-i Fünûn & 38 \\
\hline 5 alayı & Makâmât-1 Harîrî & 18 \\
\hline 4 alayı & Emir-i Pazvarî & 7 \\
\hline 6 alay 1 & İnşâ-i Kaymakam & 49 \\
\hline 1 & Kişvernâme & 49 \\
\hline 5 alayı & Çağatay-ı Türkî Osmanî & 12 \\
\hline 1 & İran Tarihi & 63 \\
\hline 1 & Lugat-1 Coğrafya & 79 \\
\hline 6 alay & Tâcü’t-tevârih & 23 \\
\hline 6 alay 1 & Logaritma & 12 \\
\hline $\begin{array}{c}20 \\
\text { alay1 }\end{array}$ & Tarih-i Farisî & 30 \\
\hline- & Evrak-1 Perişan & 20 \\
\hline 1 alayı & İlm-i Nebatât & 29 \\
\hline 81 & Divan-1 Elbise- 14 pare & $\begin{array}{r}28,14 \\
\text { para } \\
\end{array}$ \\
\hline
\end{tabular}




\begin{tabular}{|c|c|c|}
\hline 5 & Kitap kabı & 82 \\
\hline 130 & Debistân-1 Parisî- 20 pare & 65 \\
\hline 26 & Divan-1 Elbise -14 pare & 9,4 para \\
\hline 7 & Kitap kabı & 57 \\
\hline 1 & Enverî Divanı & 31 \\
\hline 100 & Müntehâb-1 Bostan-1 Sadî- 12 pare & 29 \\
\hline 4 & Kitap kabı & 249 \\
\hline $\begin{array}{c}\text { Bir } \\
\text { miktar }\end{array}$ & Abanî [Abadî] kağıt & 39 \\
\hline- & Evrak-1 Perişan & 11 \\
\hline 5 & (Defa) Kitap kabı & 31 \\
\hline 3 & Murakka & 51 \\
\hline 5 & Kitap kabı & 27 \\
\hline 6 & (Defa) Kitap kab1 & 25 \\
\hline 8 & (Defa) Kitap kab1 & 23 \\
\hline $\begin{array}{c}\text { Bir } \\
\text { miktar }\end{array}$ & Kağıt & 14 \\
\hline 1 & Cilbend & 60 \\
\hline $\begin{array}{c}\text { Bir } \\
\text { miktar }\end{array}$ & Murakka evrakı & 82 \\
\hline $\begin{array}{c}\text { Bir } \\
\text { miktar }\end{array}$ & penbe renkli kağıt & 42 \\
\hline $\begin{array}{c}\text { Bir } \\
\text { miktar }\end{array}$ & Evrak-1 perişan & 12 \\
\hline 1 & Yazı levha & 18 \\
\hline 3 & Resim levha & 11 \\
\hline 2 & (Defa) resim levha & 5 \\
\hline 3 & (Defa) resim levha & 30 \\
\hline 3 & (Defa) resim levha & 9 \\
\hline 1 & Küre & 24 \\
\hline 23 & Fransız Millet kütüphane & 20 \\
\hline 2 cild & Fransizca Doktor Biyanki[Bianchi] & 40 \\
\hline 2 & (Defa) Fransizca Doktor & 51 \\
\hline 3 & (Defa) Doktor & 19 \\
\hline 3 & (Defa) Doktor & 32 \\
\hline
\end{tabular}




\begin{tabular}{|c|c|c|}
\hline 4 & Mükaleme-i Doktor & 30 \\
\hline $\begin{array}{l}10 \\
\text { alay1 }\end{array}$ & Kondorak & 15 \\
\hline 1 & Arapça’dan Fransızca lugat & 50 \\
\hline 2 & (Defa) Tercüme & 40 \\
\hline 1 & (Defa) Tercüme & 40 \\
\hline- & Meşâhir-i müellifînden birinin Fransızca kitabı & 34 \\
\hline $\begin{array}{c}10 \\
\text { alay1 }\end{array}$ & Fransızca’dan Arapça’ya tercüme & 12 \\
\hline $\begin{array}{c}10 \\
\text { parça }\end{array}$ & Fransızca kütüb & 8 \\
\hline 9 alayı & Seyahatnâme & 22 \\
\hline 9 & (Defa) perakende Fransizca & 34 \\
\hline 3 cild & Fransızca Kâmûs & 70 \\
\hline 5 alay 1 & Fransız kütüb & 26 \\
\hline $\begin{array}{l}10 \\
\text { alay1 }\end{array}$ & $($ Defa $)$ & 34 \\
\hline $\begin{array}{c}10 \\
\text { alay1 }\end{array}$ & Gramer & 14 \\
\hline 10 & Mükâleme Türkî ve Fransevî & 13 \\
\hline $\begin{array}{c}10 \\
\text { alay1 }\end{array}$ & Molyer & 25 \\
\hline 3 alay & Kavâid-i Osmanî & 30 \\
\hline 1 & Acem Tarihi & 77 \\
\hline 1 & Fransiz Tarihi & 29 \\
\hline 1 & Çekmece & 66 \\
\hline $\begin{array}{l}\text { Bir } \\
\text { miktar }\end{array}$ & Evrâk-1 Perişan & 21 \\
\hline 2 & Kitap kabı ma' evrak & 10 \\
\hline 1 & Yazı levha & 15 \\
\hline
\end{tabular}

Müteveffâ-yı mumaileyhin ibn-i kebir-i mumaileyh Mehmed Kemal Bey'in yedinde nukûd-1 mevcudu olup kabz olunan: 2160 kuruş

Müteveffâ-yı mumaileyhin hayatında muhassas müstehak olduğu güzeşte maaşından matlubu olup nezaret-i müşarun ileyha cânibinden bâ-tezkire kabz olunan: 1200 kuruş 
Müteveffâ-yı mumaielyhin Darüşşafaka Mektebi'nden muhassas muallimlik maaşından müterâkim matlubu olup ancak kabz olunan: 3000 kuruş

\section{$\underline{33.551 \text { kuruș } 18 \text { para }}$}

40.846 kuruş 18 para

1.468 kuruş 18 para Dellaliye-i eşya-i bey 'iyye ve hamaliyye ve masârıf-1 saire 39.378 kuruş -

1.068 kuruş $\quad$ Resm-i kısmet vukiyye-i adi ve baha-i pul

38.310 kuruş Sahhül-baki li’t-taksim

Hisse-i el-zevcetü'l-mezbure İkbal Hanım : 4788,5 kuruş 30 akçe

Hisse-i el-ibnü’s-sağir el-mezbur Mehmed Cemal Bey : 11.173,5 kuruş 30 akçe

Hisse-i el-ibnü's-sağir el-mezbur Ahmed Celal Bey : 11.173,5 kuruş 30 akçe

Hisse-i el-ibn mumaileyh Mehmed Kemal Bey : 11.173,5 kuruş 30 akçe

Vekilân-1 mumaileyhimâ el-Hac Hafız Hüseyin Hüsnü Efendi ve Ahmed Muhtar Bey'den her biri müvekkilleri mumaileyhimânın bâlâda muharrer hisse-i ırsiyyeleri olan cem'an on beş bin dokuz yüz altmış iki buçuk kuruşa tereke-i müteveffâ-yı mumaileyhden tamamen ve kâmilen ahz u kabz ve istifa-yı hakk ettikten sonra sağirân-1 mezburânın kezalik bâlâda muharrer hisse-i veresiyyeleri olan cem‘an yirmi iki bin üç yüz kırk yedi buçuk kuruşun sekiz yüz kuruşunu bi'l-izni'ş-şer' sağirân-ı mezburânın nafaka-i âtiyyelerine harç ve sarf etmek üzre vasi-i mezbure İkbal Hanım bi'l-vesâye ahz u kabz etmekle lede't-tenzil mâ'adâsı olan yirmi bir bin beş yüz kırk yedi buçuk kuruşun bin yedi yüz kırk sekiz buçuk kuruşu dahi sağirân-1 mezburânın biraderi ibn-i mumaileyh Mehmed Kemal Bey zimmetinde olup tahsili derdest olmağla ba'de't-tenzil bâkisi olan on dokuz bin yedi yüz doksan dokuz kuruş vekil-i mumaileyh el-Hac Hüseyin Hüsnü Efendi marifeti ve marifet-i şer'le sağirân-1 mezburânın Bezzazistân-1 atika mahfuz sandıklarına vaz' olunduğu katib Mustafa Efendi inhâ etmekle işbu mahalle şerh olundu 


\section{Kaynaklar}

\section{Arşiv Kaynakları}

Başbakanlık Osmanlı Arşivi (BOA), Babıali Evrak Odası (BEO) 207/15458.

BOA, İrade-i Dahiliye (İ.DH) 1002/79172, 937/74233, 935/74062.

BOA, Maarif Nezareti Mektubi Kalemi (MF MKT) 3/53, 86/73, 87/28, 87/29, 87/30, 87/149, 87/74, 145/132, 168/100, 173/15, .

BOA, Maarif Nezareti Tedrisât-1 Tâliye Dairesi (MF TLY), 20/63.

BOA, Maarif Nezareti Sicill-i Ahval Şubesi (MF SCL), 2/19.

Şer’iyye Sicilleri Arşivi, Kısmet-i Askeriye Mahkemesi, nr.1940, s. 73-75.

\section{Yazmalar}

Habib İsfehani, Mecmua-i Eşar ve Fevaid, İstanbul Üniversitesi Nadir Eserler Kütüphanesi, no. FY 712.

Nizam el-Kari, Divan-ı Elbise, (Habib İsfehani müntehabatı), İstanbul Üniversitesi Nadir Eserler Kütüphanesi, no. FY 310.

Losaz Fransevi, Tercüme-i Zeyl-i Bilas (Tercüme-i Jil Bilas), İstanbul Üniversitesi Nadir Eserler Kütüphanesi, no. FY 294.

\section{Kaynak Eserler ve İncelemeler}

Abdülaziz Bey, Osmanlı Âdet, Merasim ve Tabirleri, haz. Prof. Dr. Kâzım Arısan, Duygu Arısan Günay, İstanbul: Tarih Vakfı Yurt Yayınları 1995.

Acar, M. Şinasi: Osmanlida Günlük Yaşam Nesneleri, İstanbul: Yem Yayın 2011.

Alparslan, Ali: "Habib Efendi", TDV İslâm Ansiklopedisi, XIV (Ankara 1996), s. 370-371.

Aydın, Enis Erdem: “Sultan Abdülaziz Döneminde Alfabe Tartışmaları: 'Huruf-ı Mukatta' ve Geç Tanzimat Zihniyeti”, Sultan Abdülaziz Dönemi ve Sempozyumu: Sosyo-Kültürel İlişkiler, 1 (2014) Ankara: Türk Tarih Kurumu, s. 139-152.

Birinci, Ali: “Osmanlı Devleti'nde Matbuat ve Neşriyat Yasakları Tarihine Medhal”, Taribin Hududunda Hatırat Kitapları, Matbuat Yasakları ve Arşiv Meseleleri, İstanbul: Dergâh Yayınları 2012, s. 124-201.

Bozkurt, Fatih: Tereke Defterleri ve Osmanlı Maddi Kültüründe Değişim (1785-1875 İstanbul Örneği), (Yayımlanmamış Doktora Tezi), Sakarya: Sakarya Üniversitesi Sosyal Bilimler Enstitüsü, 2011. 
Bozkurt, Fatih: "Sofrada Çatal-Bıçak Kullanımı yahut Osmanlı Sofra Âdâbının Değişimi”, Kültürümüzde Adab-ı Muaşeret, yay. haz. Azmi Özcan, Bilecik Şeyh Edebali Üniversitesi Yayınları: Bilecik 2015, s. 27-37.

Browne, Edward Granwille: Literary History of Persia (1500-1924), Cambridge: Cambridge University reprinted 1930.

Çiçekler, Mustafa: “Tanzimat sonrası Türkiye'de Farsça”, Name-i Aşina, 15-16 (Ankara 2004), s. 85-102.

Çiftçi, Hasan: "Ubeyd-i Zakani”, TDV İslâm Ansiklopedisi, XLII (Ankara 2012), s.16-17.

Çiftçi, Hasan: Ubeyd-i Zâkânî Toplumsal Görüşleri, Ablak ve Felsefesi, (Yayımlanmamış Doktora Tezi), Erzurum: Atatürk Üniversitesi, 1996.

Dığıroğlu, Filiz: "İstanbul-Tebriz Ticaret Hattında Validehan (XIX-XX. Yüzyıl)”, Türk Kültürü İncelemeleri Dergisi, 31 (İstanbul 2014), s. 69-112.

Dığıroğlu, Filiz: Dersaadet’te Acem Bir Kitapçı: Kitap-füruş Hacı Hüseyin Ağa, İstanbul: Turkuaz Yayıncılık 2014.

Erünsal, İsmail E.: Osmanlılarda Sahaflık ve Sahaflar, İstanbul: Timaş Yayınları 2013.

Findley, Carter V.: Kalemiyeden Mülkiyeye, çev. Gül Çağalı Güven, İstanbul: Tarih Vakfı Yurt Yayınları 1996.

Gurney, John: "E.G. Browne and The Iranian Community in Istanbul”, Les Iraniens T. Zarcone-F. Zarinebaf (ed.), İstanbul-Teheran 1993, pp 149-175.

Hacı Muhammed Ali Pirzade: Sefername-i Hacı Pirzade, haz. Hafiz Ferman Fermaiyan, c. I-II, Tahran 1963.

Han Melik Sasani: Payitahtın Son Yıllarında Bir Sefir, mütercim Hakkı Uygur, İstanbul: Klasik Yayınları 2006.

http://www.iranicaonline.org/articles/habib-esfahani (erişim tarihi 23.01.2015).

İnal, İbnülemin Mahmut Kemal: Son Asır Türk Şairleri, c. I, İstanbul: MEB Yayınları 1969.

Karadeniz, Yılmaz: “İran'da Malkum Han ve Feth Ali Ahundzâde’nin Arap Alfabesini Değiştirme Teşebbüsleri (1860-1880), History Studies, Enver Konukçu Armağanı, 4, s. 215-226,

Kut, Turgut: “1927’ye kadar ki Türk Yemek Kitapları Bibliyografyası”, http://www.turkishcuisine.org/article_details.php?p_id=21\&PagingIndex=0\&Pages=Articles （erişim tarihi: 16.01.2015)

Lajos, Fekete: "XVI. Yüzyılda Taşralı Bir Türk Efendi Evi”, çev. M. Tayyip Gökbilgin, Belleten, XLIII/170, Türk Tarih Kurumu: Ankara 1979, s. 457-480. 
Lawrance, Tanya E.: Akhtar: A Persian Language Newspaper Published in Istanbul and the Iranian Community of the Ottoman Empire in the Late Nineteenth Century, İstanbul: Libra Yayıncilık 2015.

Les Iraniens, (ed. T. Zarcone-F. Zarinebaf), İstanbul Teheran 1993.

Necip Asım: "Kitapçılık", İkdam, c. 53, no. 8937, 2 Cemaziyelahir 1340, s. 3

Pashazadeh, Gholamali: “Müsteşar'ul Devle ve Abdülaziz Dönemi Reformcularından Etkilenmesi”, Sultan Abdülaziz Dönemi ve Sempozyumu: Sosyo-Kültürel İlişkiler, 3 (Ankara 2014), s. 155-170.

Rahim Reis Niya, (1328 hş.). Iran ve Osmanî der Astane-i Karnı Bistum, Tahran, c.I.

Riyâhî, Muhammed Emin: Osmanlı Topraklarında Fars Dili ve Edebiyatı, Türkçesi Mehmet Kanar, İstanbul: İnsan Yayınları 1995.

Şeker, Şemsettin: Ders ile Sohbet Arasında: On dokuzuncu Asır İstanbulu'nda İlim, Kültür ve Sanat Meclisleri, İstanbul: Zeytinburnu Belediyesi 2013.

Şerifî: "Habib İsfehanî”, Danişnâme-i Edeb-i Fârisîl6, Edeb-i Fârisî der Anadolu ve Balkan, (Tahran 1383), s. 312-317.

Şerifî: "Sergüzeşt-i Hacı Baba-yı İsfehanî”, Danişnâme-i Edeb-i Fârisî/6, Edeb-i Fârisî der Anadolu ve Balkan, (Tahran 1383), s. 437-440.

Şerifî: "Sergüzeşt-i Jil Blas", Danişnâme-i Edeb-i Fârisî/6, Edeb-i Fârisî der Anadolu ve Balkan, (Tahran 1383), s. 440-441.

Türk Dili ve Edebiyatı Ansiklopedisi, III (İstanbul 1979), s. 440.

Türk Dünyası Ortak Edebiyatı: Türk Dünyası Edebiyatçıları Ansiklopedisi, IV (Ankara 2004), s. 307-308.

Türkiye'de Basılmıs Farş̧a Eserler Çeviriler ve İranla İlgili Yayınlar Bibliyografyası, Ankara 1971.

Yıldız, Güllü: “Osmanlı Matbuatının Farklı Bir Yüzü: Muhammed Tahir Tebrizî”, Türk Basın Tarihi Uluslararası Sempozyumu (19-21 Ekim 2016, Elazı̆̆), (basılmamış sempozyum bildirisi).

\section{Süreli Yayınlar}

1310 senesine mahsus Nevsal-i Servet-i Fünûn, Birinci Sene, İstanbul 1311, s. 84.

Maarif, sene 2, c. 4, nr. 97, s. 289.

Servet-i Fünun, 24 Haziran 1909, c.5, S.121, s.170. 